\title{
Photo- and Radiation-Induced One-Electron Oxidation of Methionine in Various Structural Environments Studied by Time-Resolved Techniques
}

\author{
Bronislaw Marciniak ${ }^{1, *(D)}$ and Krzysztof Bobrowski ${ }^{2, *(D)}$ \\ 1 Center for Advanced Technology, and Faculty of Chemistry, Adam Mickiewicz University, \\ Uniwersytetu Poznanskiego 10, 61-712 Poznan, Poland \\ 2 Institute of Nuclear Chemistry and Technology, Dorodna 16, 03-195 Warsaw, Poland \\ * Correspondence: marcinia@amu.edu.pl (B.M.); kris@ichtj.pl (K.B.)
}

Citation: Marciniak, B.; Bobrowski, K. Photo- and Radiation-Induced One-Electron Oxidation of Methionine in Various Structural Environments Studied by Time-Resolved Techniques. Molecules 2022, 27, 1028. https://doi.org/ $10.3390 /$ molecules 27031028

Academic Editor: Danilo Roccatano

Received: 27 December 2021

Accepted: 27 January 2022

Published: 2 February 2022

Publisher's Note: MDPI stays neutral with regard to jurisdictional claims in published maps and institutional affiliations.

Copyright: (C) 2022 by the authors. Licensee MDPI, Basel, Switzerland. This article is an open access article distributed under the terms and conditions of the Creative Commons Attribution (CC BY) license (https:// creativecommons.org/licenses/by/ $4.0 /)$.

\begin{abstract}
Oxidation of methionine (Met) is an important reaction that plays a key role in protein modifications during oxidative stress and aging. The first steps of Met oxidation involve the creation of very reactive and short-lived transients. Application of complementary time-resolved radiation and photochemical techniques (pulse radiolysis and laser flash photolysis together with time-resolved CIDNP and ESR techniques) allowed comparing in detail the one-electron oxidation mechanisms initiated either by ${ }^{\bullet} \mathrm{OH}$ radicals and other one-electron oxidants or the excited triplet state of the sensitizers e.g., 4-,3-carboxybenzophenones. The main purpose of this review is to present various factors that influence the character of the forming intermediates. They are divided into two parts: those inextricably related to the structures of molecules containing Met and those related to external factors. The former include (i) the protection of terminal amine and carboxyl groups, (ii) the location of Met in the peptide molecule, (iii) the character of neighboring amino acid other than Met, (iv) the character of the peptide chain (open vs cyclic), (v) the number of Met residues in peptide and protein, and (vi) the optical isomerism of Met residues. External factors include the type of the oxidant, $\mathrm{pH}$, and concentration of Met-containing compounds in the reaction environment. Particular attention is given to the neighboring group participation, which is an essential parameter controlling one-electron oxidation of Met. Mechanistic aspects of oxidation processes by various one-electron oxidants in various structural and $\mathrm{pH}$ environments are summarized and discussed. The importance of these studies for understanding oxidation of Met in real biological systems is also addressed.
\end{abstract}

Keywords: methionine; oxidation; neighboring group effect; hydroxyl radical; triplet state of carboxybenzophenone; one-electron oxidants; pulse radiolysis; laser flash photolysis; peptides; proteins

\section{Introduction}

Methionine (Met) is an important sulfur-containing amino acid often playing a protective role in a protein oxidation due to the fact that the thioether group is easily oxidized by many reactive species $[1,2]$. These processes play a key role in protein oxidation during oxidative stress and biological aging as certain conditions promote the conversion of sulfur radical cations into sulfoxide $[3,4]$. The first steps of oxidation mechanisms leading to proteome modifications are extremely fast, i.e., they take place within sub-microsecond and microsecond time domains [5]. They involve creation of the very reactive transients such as radicals and radical cations, which are responsible for the subsequent protein damage. For these reasons, it is important to characterize spectrally and kinetically these very first steps. Radiolysis of water and photo-excitation of benzophenone carboxyl derivatives in aqueous solutions provide very convenient source of hydroxyl radicals $\mathrm{HO}^{\bullet}$ and excited triplet states $\left(\mathrm{CB}^{*}\right)$, respectively, which were very useful for studying one-electron oxidation reactions of Met [5,6]. The transient nature of free radicals requires specific time-resolved methods. Therefore, these reactions were followed either in radiation- or photochemical 
studies by means of pulse radiolysis [7-14], laser flash photolysis [15-22], CIDNP [23-25], and ESR techniques [26]. They were the subject of several review articles [6,27-30], and also chapters in books [31-35], presenting free radical chemistry in amino acids, peptides, and proteins in a more general manner.

A wealth of knowledge has been accumulated concerning mechanistic understanding of these processes induced by one-electron oxidation of methionine in various structural environments. To analyze the oxidation mechanism of methionine, one has to take into account that methionine can exist in cationic, zwitterionic, or anionic forms in aqueous solutions depending on the $\mathrm{pH}$ range with the respective $\mathrm{p} K_{\mathrm{a}}$ values: $\left(\mathrm{COOH} / \mathrm{COO}^{-}\right)=2.3$ and $\left({ }^{+} \mathrm{NH}_{3} / \mathrm{NH}_{2}\right)=9.2$ (Figure 1$)$.

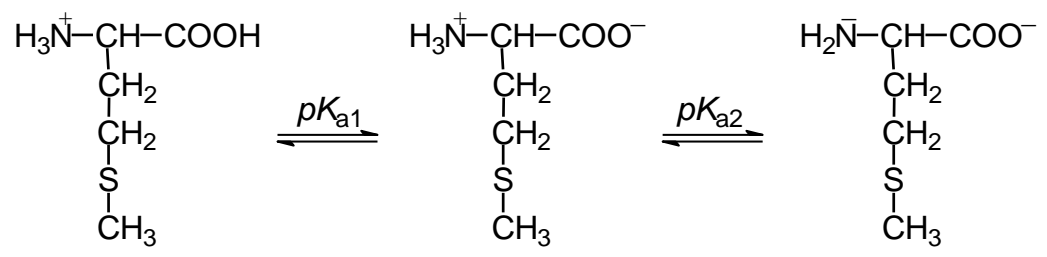

Figure 1. Structures of methionine in aqueous solutions at $\mathrm{pH}$ range 1-14.

Neighboring group participation is also an important concept for understanding how the one-electron oxidation of methionine is controlled. This is the case when a neighboring group stabilizes a transition state or intermediate by becoming bonded to the reaction center as a result of "through space" interaction [36]. These neighboring groups can provide a lone pair of electrons which can be shared with the monomeric sulfur cation center, $>S^{\bullet+}$, forming a three-electron-bonded species which effectively stabilizes the radical cation. The same applies to the ${ }^{\bullet} \mathrm{OH}$-induced oxidation of methionine where the ${ }^{\bullet} \mathrm{OH}$ radicals directly attack the sulfur, forming three-electron-bonded adduct $(>\mathrm{S} . \therefore \mathrm{OH})$, and its subsequent reactions are strongly influenced by the presence of neighboring groups (Figure 2).

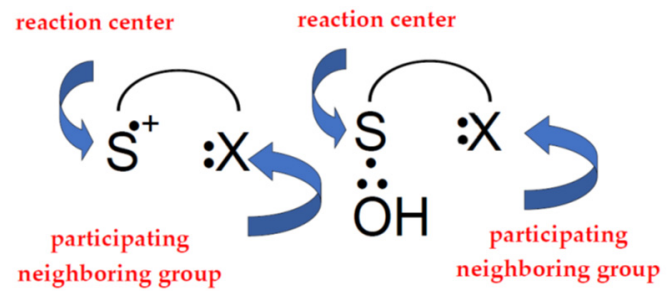

Figure 2. Simplified scheme showing neighboring group participation during oxidation of thioether group of methionine.

Neighboring group participation in the reactions of two intermediates, monomeric sulfur radical cations $\left(\mathrm{MetS}^{\bullet+}\right.$ ), and $\mathrm{OH}$-adducts to the sulfur atom (MetS. $: \mathrm{OH}$ ) during Met oxidation is of great importance, particularly within peptides and proteins. This is due to the presence of a manifold of possible participating functionalities such as carboxyl, amine, hydroxyl, amide, and thioether groups [37]. For a long time it was believed that the intramolecular two-centered, three electron (2c-3e) bonds between the oxidized sulfur atom in Met and the lone electron pair on the nitrogen atom in N-terminal amino group and/or the oxygen atoms in the C-terminal carboxyl group are responsible for stabilization of $\mathrm{MetS}^{\bullet+}$ ). Such stabilization leads to five-membered intramolecularly S. $\mathrm{N}$-bonded species and/or six-membered intramolecularly S. :O-bonded species. Subsequent studies showed that heteroatoms present in the peptide bond can be also involved in the formation of similar 2c-3e bonds with the oxidized sulfur atom. The general description and spectral characterization of two-centered, three electrons (2c-3e) species was summarized and extensively discussed in numerous papers [38-40], book chapters [41,42], and references therein.

The main purpose of this review is to present various factors that might influence the character of intermediates forming during one-electron oxidation of methionine. They 
can be divided into two parts: those inextricably related to the structure of molecules containing methionine, and those related to the external factors. The former include: (i) protection of terminal amine and carboxyl groups, (ii) location of methionine in the peptide molecule (N/C-terminal and internal), (iii) character of the neighboring amino acid other than methionine, (iv) character of the peptide chain (open vs. cyclic), (v) number of methionine residues in the peptide molecule, and (vi) optical isomerism of methionine residues. In turn, external factors include: (i) type of radiation that induces the oxidation (light vs. high-energy radiation), (ii) type of the oxidant $\left({ }^{\bullet} \mathrm{OH}\right.$ vs one-electron oxidant), and (iii) $\mathrm{pH}$ and concentration of Met-containing molecules in the reaction environment.

Application of complementary radiation and photochemical techniques allowed investigators to compare in detail the one-electron oxidation mechanisms initiated either by ${ }^{\bullet} \mathrm{OH}$ radicals and other one-electron oxidants or the excited triplet state of the sensitizer $\left(\mathrm{CB}^{*}\right)$. The complete and detailed description of the primary steps of the oxidation mechanisms of Met residues located in the interior of long oligopeptides and proteins is a significant and original contribution in understanding oxidation reactions in real biological systems which might be of great help in imagining new strategies in the struggle against "uncontrolled oxidative stress". The results of these studies and conclusions drawn from them are summarized in this review.

\section{Methionine and Methionine Derivatives}

\subsection{Radiation-Induced Oxidation}

\subsubsection{Methionine}

In the 1980s, the reactions of ${ }^{\bullet} \mathrm{OH}$ radicals and some selected one-electron oxidants with Met were extensively studied by Asmus' group in order to characterize spectral and kinetic properties of sulfur- and carbon-centered radicals which can be potentially formed [7,43-46]. Mechanistic studies of the radically induced oxidation of Met revealed rather complex reaction schemes which depend mainly on three parameters, the nature of the oxidant, $\mathrm{pH}$ of the solution, and concentration of Met. Although ${ }^{\bullet} \mathrm{OH}$ radicals exhibit strong oxidation properties (the standard reduction potentials of the $\mathrm{HO}^{\bullet} / \mathrm{HO}^{-}$and $\mathrm{HO}^{\bullet}$, $\mathrm{H}^{+} / \mathrm{H}_{2} \mathrm{O}$ redox couples are equal to $\mathrm{E}^{0}=+1.90 \mathrm{~V}$ and $+2.72 \mathrm{~V}$ vs. NHE, respectively) [47], their oxidation action is not a straightforward one-electron transfer process. Owing to their high electrophilicity the $\mathrm{HO}^{\bullet}$ radicals prefer to add to the sulfur atom which is a reaction center of high electron density.

The underlying mechanism of the ${ }^{\bullet} \mathrm{OH}$-induced oxidation of Met is based on an addition of the electrophilic ${ }^{\bullet} \mathrm{OH}$ radical to the sulfur atom forming MetS. $\mathrm{OH}$ as the initial step. This reaction occurs with an absolute rate constant $k=2.3 \times 10^{10} \mathrm{M}^{-1} \mathrm{~s}^{-1}$ (vide Table 1), irrespective of $\mathrm{pH}$, and is practically only controlled by diffusion of the reactants. The consecutive steps depend further on $\mathrm{pH}$. In strong acid solutions $(\mathrm{pH} \leq 3) \mathrm{MetS} \cdot \mathrm{OH}$ will react with external protons yielding $\mathrm{MetS}^{\bullet+}$. At a low concentration of Met, MetS $\mathrm{S}^{\bullet+}$ undergoes deprotonation that leads to $\alpha$-(alkylthio)alkyl radicals $\left(k=2.4 \times 10^{5} \mathrm{~s}^{-1}\right)$ (in the following referred to as $\alpha$-S1 and $\alpha$-S2 with estimated $\mathrm{pK}$ a $\left(\operatorname{Met} S^{\bullet}+/ \operatorname{Met}\left(-{ }^{\bullet} \mathrm{CHSCH}_{3}\right)=-6\right.$ for deprotonation in the $\gamma$-position and $\mathrm{pK} \mathrm{a}_{\mathrm{a}}\left(\mathrm{Met} \mathrm{S}^{\bullet}+/ \operatorname{Met}\left({ }^{\bullet} \mathrm{CH}_{2} \mathrm{SCH}_{2}-\right)=-2\right.$ for deprotonation in the $\varepsilon$-position [48]. At high concentration of $\mathrm{Met}, \mathrm{MetS}^{\bullet+}$ can be stabilized via intermolecular equilibration with a second unattacked Met molecule forming a dimeric sulfur radical cation with an intermolecular $2 \mathrm{c}-3 \mathrm{e}$ S..$S$ bond ((MetS. SMet) $\left.{ }^{+}\right)$. This dimeric radical cation is characterized by a strong absorption spectrum with $\lambda_{\max }=480 \mathrm{~nm}$. In principle, in acidic conditions Met behaves like an ordinary thioether. At $\mathrm{pH} \geq 3$, where the carboxyl group is deprotonated, the oxidative mechanism is changed and involves an intramolecular process where protons for dihydroxylation of MetS: $\mathrm{OH}$ are provided by the ${ }^{+} \mathrm{NH}_{3}$ group. The latter process leads to formation of an intramolecularly $\mathrm{S} \cdot \mathrm{N}$-bonded intermediate (in the following referred to as $S \cdot \mathrm{N}$-bonded radical cation, $\operatorname{Met}(\mathrm{S} \cdot \mathrm{N})^{+}$) which is assisted by a suitable five membered ring steric arrangement. The $\left.\operatorname{Met}(S \cdot N)^{+}\right)$is a veryshort lived intermediate $\left(\tau_{1 / 2}=220 \mathrm{~ns}\right)$ and exhibits a transient absorption spectrum with $\lambda_{\max } \approx 390-400 \mathrm{~nm}$ [46]. The consecutive reactions include opening of the $\mathrm{S} \cdot \mathrm{N}$-bond to the 
$\mathrm{N}$-centered radical cation $\mathrm{H}_{2} \mathrm{~N}^{\bullet+}$ - $\mathrm{CHR}-\mathrm{COO}^{-}$, establishment of the mesomeric form, $\mathrm{H}_{2} \mathrm{~N}$ CHR-COO ${ }^{\bullet}$ and $\mathrm{CO}_{2}$ cleavage of the latter with the formation of 3-methylthiopropylamino radical (in the following referred to as an $\alpha$-amino radical, $\alpha-\mathrm{N}$ ). The most important consequences of the mechanism change are decarboxylation of the Met molecule and formation of $\alpha$-N radicals with strong reductive properties. Formation of the latter radical changes the redox properties of the system from oxidizing to reducing. The general reaction mechanism describing the primary and secondary reactions of radiationally induced ${ }^{\bullet} \mathrm{OH}$ radicals in aqueous solutions is presented in Scheme 1.

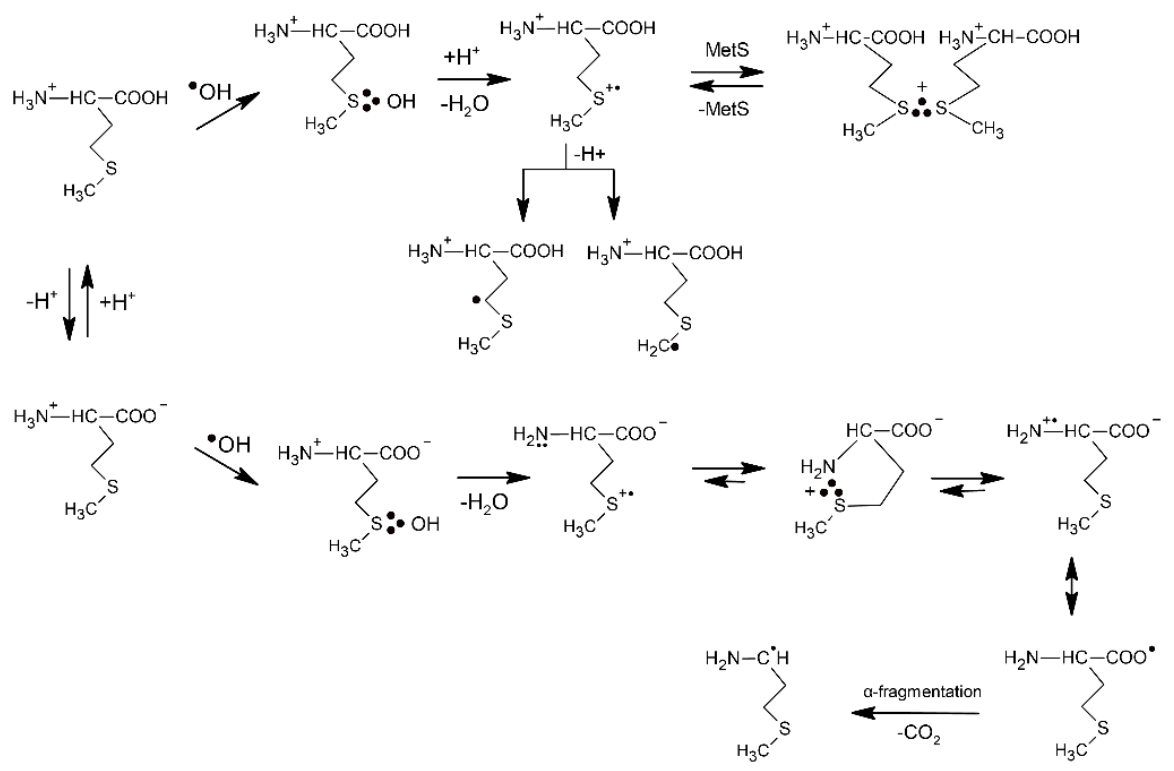

Scheme 1. The reactions mechanism for ${ }^{\bullet} \mathrm{OH}$-induced oxidation of methionine (based on $[7,46]$ ).

A significantly different picture with respect to $\mathrm{pH}$ is observed in the oxidation of Met by the $\mathrm{CCl}_{3} \mathrm{O}_{2}{ }^{\bullet}$ radicals (a moderately good one-electron oxidant) [45]. Its reduction potential depends on $\mathrm{pH}: \mathrm{E}^{0}\left(\mathrm{CCl}_{3} \mathrm{OO}{ }^{*}, \mathrm{H}^{+} / \mathrm{CCl}_{3} \mathrm{OOH}\right)=1.60 \mathrm{~V}$ vs. NHE and $\mathrm{E}^{0}\left(\mathrm{CCl}_{3} \mathrm{OO} \bullet / \mathrm{CCl}_{3} \mathrm{OO}^{-}\right)=1.15$ vs. NHE [49]. The reaction of Met with $\mathrm{CCl}_{3} \mathrm{OO} \bullet$ radicals proceeds with $\mathrm{k}=2.9 \times 10^{7} \mathrm{M}^{-1} \mathrm{~s}^{-1}$ (vide Table 1). The normalized plots for the formation of the (MetS. SMet) ${ }^{+}$and Met(S. $\left.\cdot \mathrm{N}\right)^{+}$resulting from the oxidation of Met by ${ }^{\bullet} \mathrm{OH}$ and $\mathrm{CCl}_{3} \mathrm{O}_{2}{ }^{\circ}$ and based on their absorptions at the respective $\lambda_{\max }=480$ and $390 \mathrm{~nm}$ clearly indicate that in contrast to the system containing ${ }^{\bullet} \mathrm{OH}$, the dimeric (MetS. $\left.\cdot \mathrm{SMet}\right)^{+}$radical cations are stabilized over the entire acid and neutral $\mathrm{pH}$ range before they are replaced by $\operatorname{Met}(\mathrm{S} \cdot \mathrm{N})^{+}$radical cations. An exclusive formation of the $\operatorname{Met}(\mathrm{S} \cdot: \mathrm{N})^{+}$intermediate occurs at $\mathrm{pH}>9$ in contrast to the reaction of ${ }^{\bullet} \mathrm{OH}$ where the $\operatorname{Met}(\mathrm{S} \cdot \mathrm{N})^{+}$intermediate is almost exclusively formed at $\mathrm{pH}>4$. The apparent change in reaction mechanism occurs in slightly more basic solutions, i.e., near the $\mathrm{pK}_{\mathrm{a} 2}$ of the amino group in Met (vide Figure 1). The formation of $\operatorname{Met}(\mathrm{S} \cdot: \mathrm{N})^{+}$in the system containing $\mathrm{CCl}_{3} \mathrm{O}_{2} \cdot$ requires the availability of the free electron pair of the unprotonated amino function and therefore this species is only formed beyond and near the $\mathrm{pK}_{\mathrm{a} 2}$ [45]. The oxidation mechanism of Met by $\mathrm{CCl}_{3} \mathrm{O}_{2}{ }^{\bullet}$ and also by other one-electron oxidants such as $\mathrm{CF}_{3} \mathrm{CHClO}_{2}{ }^{\bullet}$ [45], $\mathrm{CO}_{3}{ }^{--}$[50], $\mathrm{Tl}^{2+}$ [43], and $\mathrm{Ag}^{2+}$ [43] is exemplified in Scheme 2. Their respective rate constants with Met are listed in Table 1 . The parameter which essentially controls whether $(\operatorname{MetS}: \mathrm{SMet})^{+} \operatorname{or} \operatorname{Met}(\mathrm{S} \cdot: \mathrm{N})^{+}$is formed is the equilibrium constant $K_{\mathrm{a} 2}$ (see Figure 1). However, the kinetics of associated processes have to be also taken into account. 


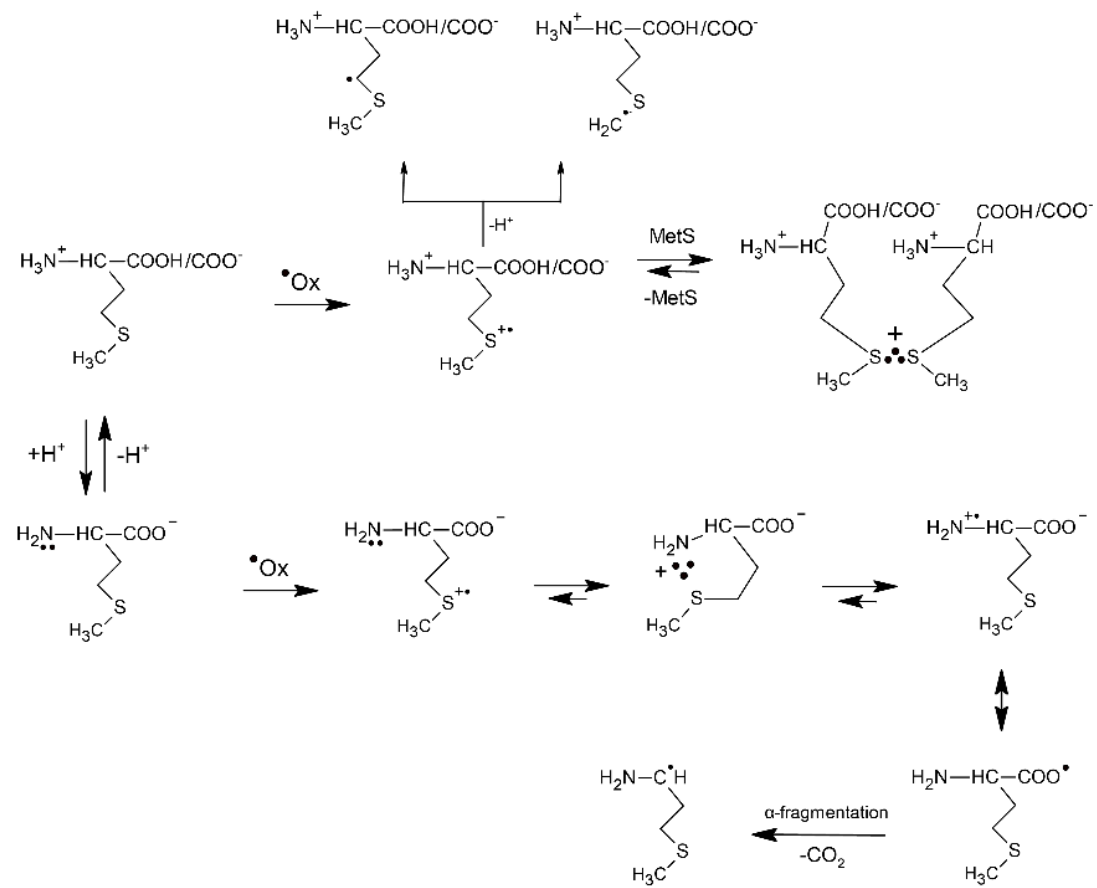

Scheme 2. The general reactions mechanism for ${ }^{\bullet} \mathrm{Ox}$-induced oxidation of methionine in aqueous solutions where ${ }^{\bullet} \mathrm{Ox}=\mathrm{CCl}_{3} \mathrm{O}_{2}{ }^{\bullet}, \mathrm{CF}_{3} \mathrm{CHClO}_{2}{ }^{\bullet}, \mathrm{CO}_{3}^{\bullet-}, \mathrm{Tl}^{2+}, \mathrm{Ag}^{2+}$ (based on [43,45]).

Although $\mathrm{Cl}_{2}{ }^{\bullet-}$ radicals exhibit strong oxidation properties (the standard reduction potential of the $\mathrm{Cl}_{2}{ }^{\bullet-} / 2 \mathrm{Cl}^{-}$redox couple is equal to $\mathrm{E}^{0}=+2.13 \mathrm{~V}$ vs. NHE [47]), their oxidation action is not an adduct mediated one-electron transfer process (an inner-sphere electron transfer) such as in the case of ${ }^{\bullet} \mathrm{OH}$ radicals. Moreover, this reaction could be studied only in very acid solutions owing to the complex reaction mechanism leading to $\mathrm{Cl}_{2}{ }^{\bullet-}$ formation in aqueous solutions and involving ${ }^{\bullet} \mathrm{OH}$ radicals, $\mathrm{HOCl}^{\bullet-}$ radical anions, protons $\left(\mathrm{H}^{+}\right)$and chlorine atoms $\left(\mathrm{Cl}^{\bullet}\right)$ [51]. The primary step of Met oxidation by $\mathrm{Cl}_{2}{ }^{\bullet-}$ radicals was found to be, in principle, similar to that established for the ${ }^{\bullet} \mathrm{OH}$ radicals and occurs with absolute rate constant $k=3.9 \times 10^{10} \mathrm{M}^{-1} \mathrm{~s}^{-1}$ (see Table 1) [52]. It is characterized by a primary attack on the sulfur atom that constitutes a substitution of a chloride anion $\left(\mathrm{Cl}^{-}\right)$in $\mathrm{Cl}_{2}{ }^{--}$by Met and leads to the MetS. $\therefore \mathrm{Cl}$ three-electron bonded species. Interestingly, from the earlier studies on the oxidation of simple thioethers it is known that MetS. $: X$ species are involved in the following equilibrium with (MetS. $:$ SMet) ${ }^{+}$ radical cations: MetS. $: X+$ MetS $\leftrightarrows(\text { MetS } \cdot: \text { SMet })^{+}+\mathrm{X}^{-}[53]$

The reactions mechanism for $\mathrm{Cl}_{2}{ }^{\bullet-}$-induced oxidation of Met is presented in Scheme 3 and clearly shows that a monomeric sulfur radical cation $\mathrm{MetS}^{\bullet+}$ can be stabilized not only in a form of the dimeric (MetS. SMet) ${ }^{+}$radical cations but also in a form of MetS. $\mathrm{Cl}$ three-electron bonded species with the chloride anions $\mathrm{Cl}^{-}$providing a free electron pair. The validity of the mechanism (Scheme 3 ) was also experimentally demonstrated in the oxidation of Met by $\mathrm{Br}_{2}{ }^{\bullet-}$ where the corresponding MetS. . Br species were also observed at neutral and basic $\mathrm{pHs}$. The observed decrease in rate constant for the reaction of Met with $\mathrm{Br}_{2}{ }^{\bullet-}\left(k=2.5 \times 10^{10} \mathrm{M}^{-1} \mathrm{~s}^{-1}\right)$ correlates well with the standard reduction potential of the $\mathrm{Br}_{2}{ }^{\bullet-} / 2 \mathrm{Br}^{-}$redox couple which is equal to $\mathrm{E}^{0}=+1.63 \mathrm{~V}$ vs. NHE (see Table 1) [47]. The actual reaction routes are very sensitive to a variety of parameters such as $\mathrm{pH}$, Met and $\mathrm{Cl}^{-} / \mathrm{Br}^{-}$concentration. 


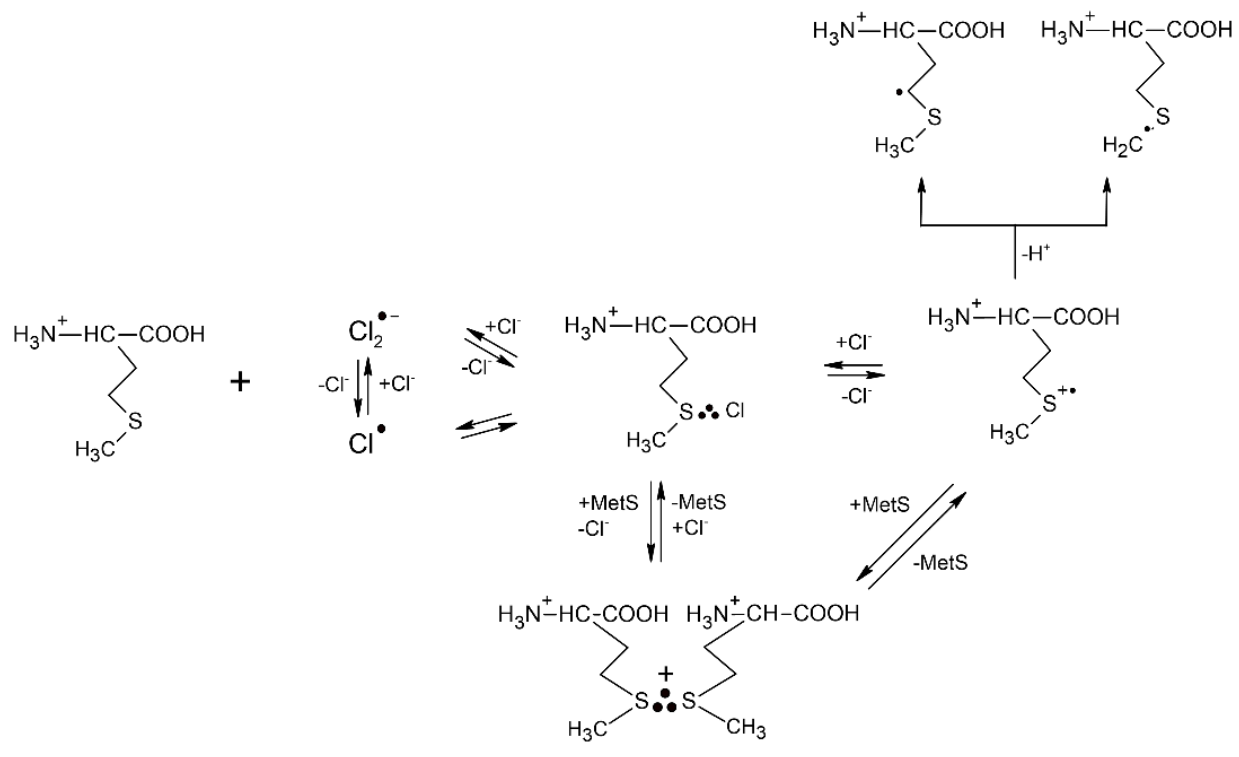

Scheme 3. The reactions mechanism for $\mathrm{Cl}_{2}{ }^{\bullet-}$-induced oxidation of methionine in aqueous solutions (based on [52]).

Table 1. Rate constants of reactions of ${ }^{\bullet} \mathrm{OH}$ radical and various one-electron oxidants $\left({ }^{\bullet} \mathrm{Ox}\right)$ with methionine in aqueous solutions.

\begin{tabular}{|c|c|c|c|c|c|}
\hline Oxidant & $\begin{array}{c}\operatorname{Met}\left(\mathrm{NH}_{3}{ }^{+},\right. \\
\mathrm{COOH})\end{array}$ & $\begin{array}{c}\operatorname{Met}\left(\mathrm{NH}_{3}{ }^{+}\right. \\
\left.\mathrm{COO}^{-}\right)\end{array}$ & $\begin{array}{c}\mathrm{Met}_{\left(\mathrm{NH}_{2}\right.} \\
\left.\mathrm{COO}^{-}\right)\end{array}$ & $\mathrm{E}^{0(a)}$ & Lit \\
\hline$\cdot \mathrm{OH}$ & $2.3 \times 10^{10(b)}$ & & & +2.72 & [7] \\
\hline $\mathrm{CCl}_{3} \mathrm{O}_{2} \bullet$ & & & $2.9 \times 10^{7(b, c)}$ & +1.60 & [45] \\
\hline $\mathrm{CF}_{3} \mathrm{CHClO}_{2}{ }^{\bullet}$ & & & $1.4 \times 10^{6(b, c)}$ & +1.15 & [45] \\
\hline $\mathrm{CO}_{3}^{\bullet-}$ & & $3.6 \times 10^{7(b)}$ & & +1.57 & [50] \\
\hline $\mathrm{Cl}_{2}^{\bullet-}$ & $3.9 \times 10^{9}(\mathrm{~b})$ & & & +2.13 & [52] \\
\hline $\mathrm{Br}_{2} \bullet-$ & $2.5 \times 10^{9(b)}$ & $1.7 \times 10^{9(\mathrm{~b})}$ & $2.0 \times 10^{9(b, c)}$ & +1.63 & [52] \\
\hline $\mathrm{Tl}^{2+}$ & & $2.5 \times 10^{9(b)}$ & & +2.23 & [43] \\
\hline $\mathrm{Ag}^{2+}$ & & $3.3 \times 10^{8(b)}$ & & +1.98 & [43] \\
\hline
\end{tabular}

(a) all reduction potentials in V vs. NHE after reference [47], ${ }^{(b)}$ rate constants in $\mathrm{M}^{-1} \mathrm{~s}^{-1}$ units, ${ }^{(\mathrm{c})}$ measured by competition method.

\subsubsection{Methionine Derivatives}

Selective protection of the N-terminal and C-terminal groups in Met enabled investigators to elucidate the role of each individual neighboring group $\mathrm{NH}_{3}{ }^{+} / \mathrm{NH}_{2}$ and $\mathrm{COOH} / \mathrm{COO}^{-}$in one-electron oxidation of Met by ${ }^{\bullet} \mathrm{OH}$ radicals. The following methionine derivatives were included in the studies: N-acetyl-methionine (N-Ac-Met) [7,54,55], methionine methyl ester (Met- $\mathrm{C}(=\mathrm{O}) \mathrm{CH}_{3}[54,56]$, and methionine ethyl ester (Met- $\mathrm{C}(=\mathrm{O})$ $\mathrm{CH}_{2} \mathrm{CH}_{3}$ [46].

Substitution of one of the hydrogen atoms in the amino group $\left(-\mathrm{NH}_{2}\right)$ by an acetyl group $\left.(-\mathrm{C}=\mathrm{O})-\mathrm{CH}_{3}\right)$ does not change the initial reaction of ${ }^{\bullet} \mathrm{OH}$ radicals with the sulfur atom in N-Ac-Met. The observed transient absorption bands at $\mathrm{pH} 7$ with $\lambda_{\max }=290,340$, and $480 \mathrm{~nm}$ were respectively assigned to $\alpha$-S1 / $\alpha$-S2 derived from N-Ac-Met, N-Ac-MetS. $\mathrm{OH}$, and (N-Ac-MetS: SMet-N-Ac) ${ }^{+}$species. However, the following features distinguish N-AcMet from Met: (i) prolonged lifetime of N-Ac-MetS. OH, and (ii) absence of the absorption band which can be assigned to $\mathrm{N}-\operatorname{Ac}-\operatorname{Met}(\mathrm{S} \cdot \mathrm{N})^{+}$. Based on these observations, it can be concluded that the protonated amino group in Met plays a role of intramolecular proton donor in the disappearance of MetS: $\mathrm{OH}$, and later being in the deprotonated form $\left(-\mathrm{NH}_{2}\right)$ as a donor of free electron pair for stabilization of $\operatorname{Met}(\mathrm{S} \cdot \mathrm{N})^{+}$. Depending on N-Ac-Met concentration, the monomeric sulfur radical cation $\mathrm{N}-\mathrm{Ac}-\mathrm{Met} \mathrm{S}^{\bullet+}$, similarly as in Met, can be stabilized via intermolecular equilibration with a second unattacked N-Ac-Met 
molecule forming a dimeric sulfur radical cation with intermolecular $2 \mathrm{c}-3 \mathrm{e} \mathrm{S} \cdot \mathrm{S}$ bond ((NAc-MetS: SMet-N-Ac) ${ }^{+}$) and further undergo deprotonation to $\alpha-S 1 / \alpha-S 2$ radicals (see Scheme 1). Detection of $\mathrm{CO}_{2}$ in the system studied $[7,44]$, clearly indicates that N-Ac-MetS ${ }^{\bullet+}$ can undergo decarboxylation via pseudo-Kolbe mechanism to form N-Ac-substituted $\alpha-\mathrm{N}$ radicals $[57,58]$.

The replacement of the carboxyl group with an ester or an amide group in methionine does not significantly change the primary radical reactions related to the oxidation process, except for the fact that the decarboxylation process involving the intramolecular Met $(\mathrm{S} \cdot \mathrm{N})^{+}$ is inhibited (see Scheme 1$)$. This is reflected in much longer lifetime $\left(\tau_{1 / 2} \sim 1.1 \mathrm{~ms}\right.$ ) of this radical, which was directly observed in the example of the methionine ethyl ester [46].

Simultaneous acetylation of the N-terminal amino group and either esterification or amidation of the C-terminal carboxyl group was aimed at elimination of the fast intramolecular proton transfer from the amino group to the MetS. $\mathrm{OH}$ moiety and elimination of decarboxylation of the Met residue via pseudo Kolbe mechanism, respectively. In addition, the insertion of these groups in the methionine molecule allows formation of structural motifs that quite well mimic peptide bonds in peptides and proteins. Two methionine derivatives, $\mathrm{N}$-acetyl methionine amide $\left(\mathrm{N}-\mathrm{Ac}-\mathrm{Met}-\mathrm{NH}_{2}\right)$ [10], and methyl ester of N-acetylmethionine $\left(\mathrm{N}-\mathrm{Ac}-\mathrm{Met}-\mathrm{OCH}_{3}\right)$ [11,59], were selected in order to limit stabilization of the monomeric sulfur radical cations $\left(\mathrm{MetS}^{\bullet+}\right)$ only to interactions with $\mathrm{N}$ - and $\mathrm{O}$-atoms located in acetyl, ester and amide functional groups. Furthermore, they allow one to establish and to prove the mechanisms for primary and secondary radical reactions following oxidation of the Met residue by ${ }^{\bullet} \mathrm{OH}$ radicals with no contribution of free terminal amino and carboxyl groups. Thus, they can be considered to be the simplest models of Met residue incorporated in the interior of oligopeptides and proteins. The general reaction mechanism describing the primary and secondary reactions of radiationally induced $\bullet \mathrm{OH}^{\circ}$ radicals with these Met derivatives in aqueous solutions together with the respective intermediates is presented in Section 2.2.2.

\subsection{Photo-Induced Oxidation}

The mechanism for the quenching of the benzophenone triplet state $\left({ }^{3} \mathrm{Bz}\right)$ by sulfurcontaining organic compounds, e.g., thioethers, has been studied since the 1970s [60]. It was suggested that quenching leads to the formation of partial charges on sulfur and oxygen atoms (Charge Transfer (CT)-complex) decaying by the proton transfer from the carbon atom bonded to the sulfur atom to form the ketyl radical and $\alpha$-(alkylthio)alkyl radical $(\alpha S)$ and back electron transfer to regenerate reactants in their ground states (see Scheme 4).

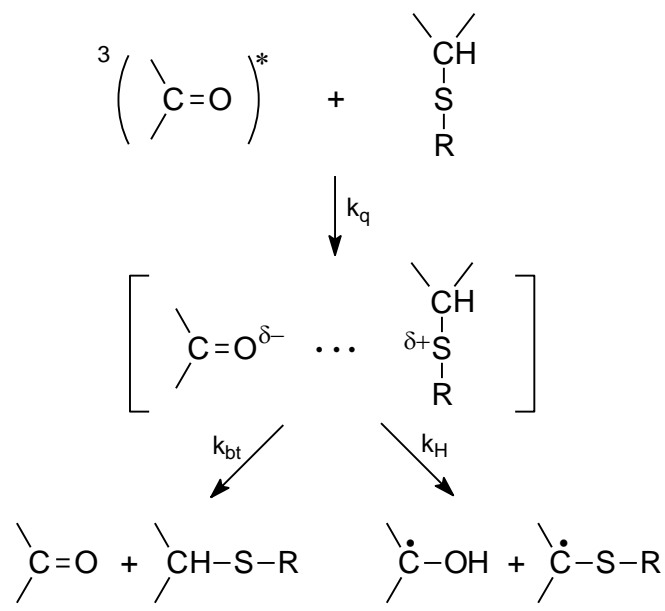

Scheme 4. The mechanism for the quenching of ${ }^{3} \mathrm{Bz}$ by thioethers (based on [60]).

To analyze the mechanism of quenching of carboxybenzophenone (CB) triplets by methionine, methionine derivatives and peptides ( $\mathrm{S}$ and $\mathrm{N}$ atoms as the expected electron 
donors), one has to take into account that methionine can exist in zwitterionic (at pH 7) or anionic forms (at $\mathrm{pH} 11$ ) in aqueous solutions depending on the $\mathrm{pH}$ range (see Figure 1). Therefore, the quenching rate constants for quenching the CB triplet in aqueous solutions by methionine, and Met derivatives and for comparison simple Met-containing peptides (Table 2) are presented at two representative $\mathrm{pH}$ values 7 and 10/11.

It was proven that the $\mathrm{CB}$ triplet quenching by methionine and Met-containing compounds were occurring via an electron transfer mechanism from its S-atom (not its $\mathrm{N}$-atom) based on the following arguments [18,61]:

- $\quad$ as shown in Table 2, the quenching rate constants were found to be in the range of $10^{9} \mathrm{M}^{-1} \mathrm{~s}^{-1}$ (diffusion controlled limit) for methionine and Met-containing compounds and were, respectively, three orders or one order of magnitude lower for amino acids without a sulfur atom (e.g., alanine) at $\mathrm{pH} 7$ and $\mathrm{pH} 10$,

- direct observation of radical-ion products in the transient absorption spectra (electron transfer intermediates, among them various two-center three-electron $(2 c-3 e)$ bonded species) were products of oxidation of Met and CB radical anions and CB ketyl radicals were products of CB reduction,

- $\quad$ indirectly by the Rehm-Weller correlations of $k_{\mathrm{q}} \mathrm{vs} . \Delta \mathrm{G}_{\mathrm{el}}$ (free energy change for electron transfer).

Similar arguments for an electron transfer mechanism of quenching were applied for methionine derivatives with blocked amino and/or carboxylic terminal groups and simple peptides containing methionine residues $[16,18,19,22,62,63]$.

Table 2. Quenching rate constants $\left(k_{\mathrm{q}} \times 10^{-9} \mathrm{M}^{-1} \mathrm{~s}^{-1}\right)$ for quenching of CB triplet in aqueous solutions by methionine, Met derivatives and simple Met-containing peptides [15,16,18-20,62].

\begin{tabular}{ccc}
\hline Amino Acid or Peptide & pH 7 & pH 10/11 \\
\hline Methionine & 2.5 & 2.3 \\
N-Ac-Met & 1.9 & 1.6 \\
Met-OCH 3 & 3.0 & 2.9 \\
Met-Gly & 2.1 & 2.3 \\
Gly-Met & 2.0 & 2.0 \\
Met-Lys & 1.8 & 1.3 \\
Lys-Met & 2.5 & 1.8 \\
Met-Gly-Gly & 2.3 & 2.2 \\
Gly-Gly-Met & 1.8 & 1.9 \\
Met-Met & 2.9 & 1.8 \\
Met-Enkephalin & 1.9 & 1.8 \\
Alanine & $<0.0005$ & 0.18 \\
\hline
\end{tabular}

estimated errors: $<10 \%$.

\subsubsection{Methionine}

The study of the photooxidation mechanism of methionine in aqueous solution started with the pioneering work of Cohen [64]. The suggested mechanism of primary reactions was described by formation of two CT complexes: CT-S $\left[\mathrm{CB}^{\bullet-} \ldots>\mathrm{S}^{\bullet+}\right]$ and $\mathrm{CT}-\mathrm{N}\left[\mathrm{CB}^{\bullet-}\right.$ $\ldots>\mathrm{N}^{\bullet+}$ ] but only CT-N complex could undergo decarboxylation leading to the formation of $\alpha$-amino-alkyl radical $(\alpha \mathrm{N})$. The latter could reduce the ground state CB yielding ketyl radical $\left(\mathrm{CBH}^{\bullet}\right)$ and methional (Scheme 5).

Further studies using nanosecond flash photolysis technique $[15,62,65,66]$ led to a more detailed description of primary and secondary reactions for the photooxidation of methionine in neutral and basic aqueous solutions. These reactions are presented in Schemes 6 and 7. 


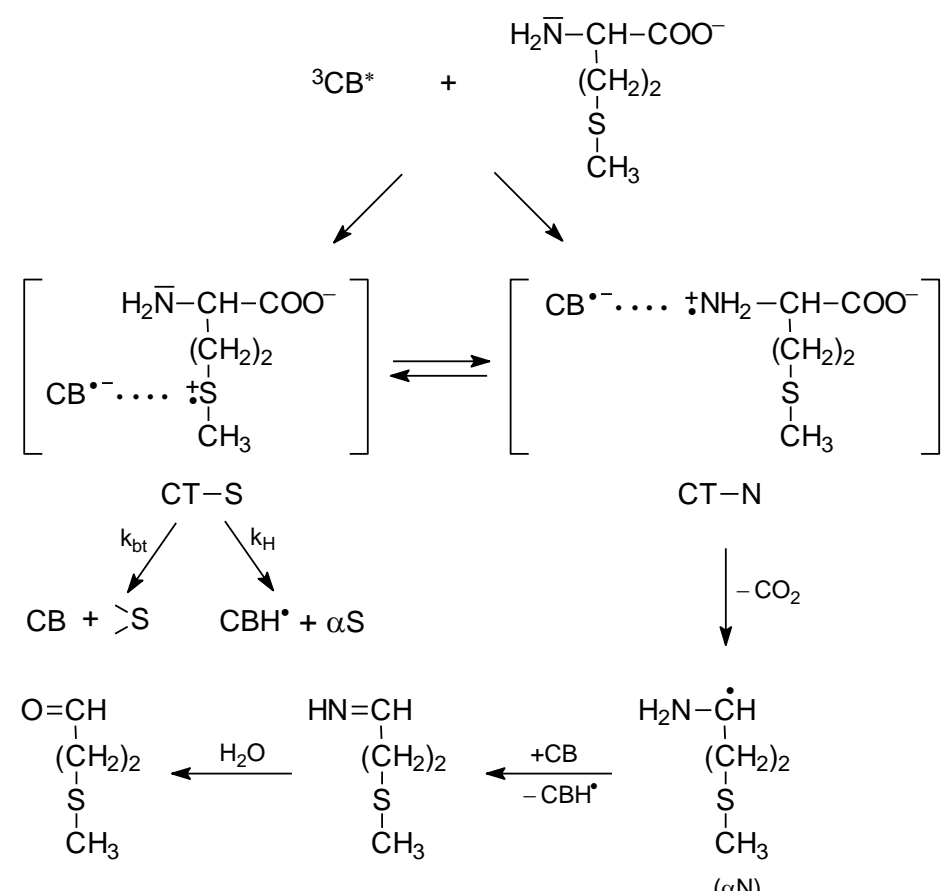

Scheme 5. The mechanism of CB-sensitized photooxidation of methionine in alkaline aqueous solutions (based on [64]).

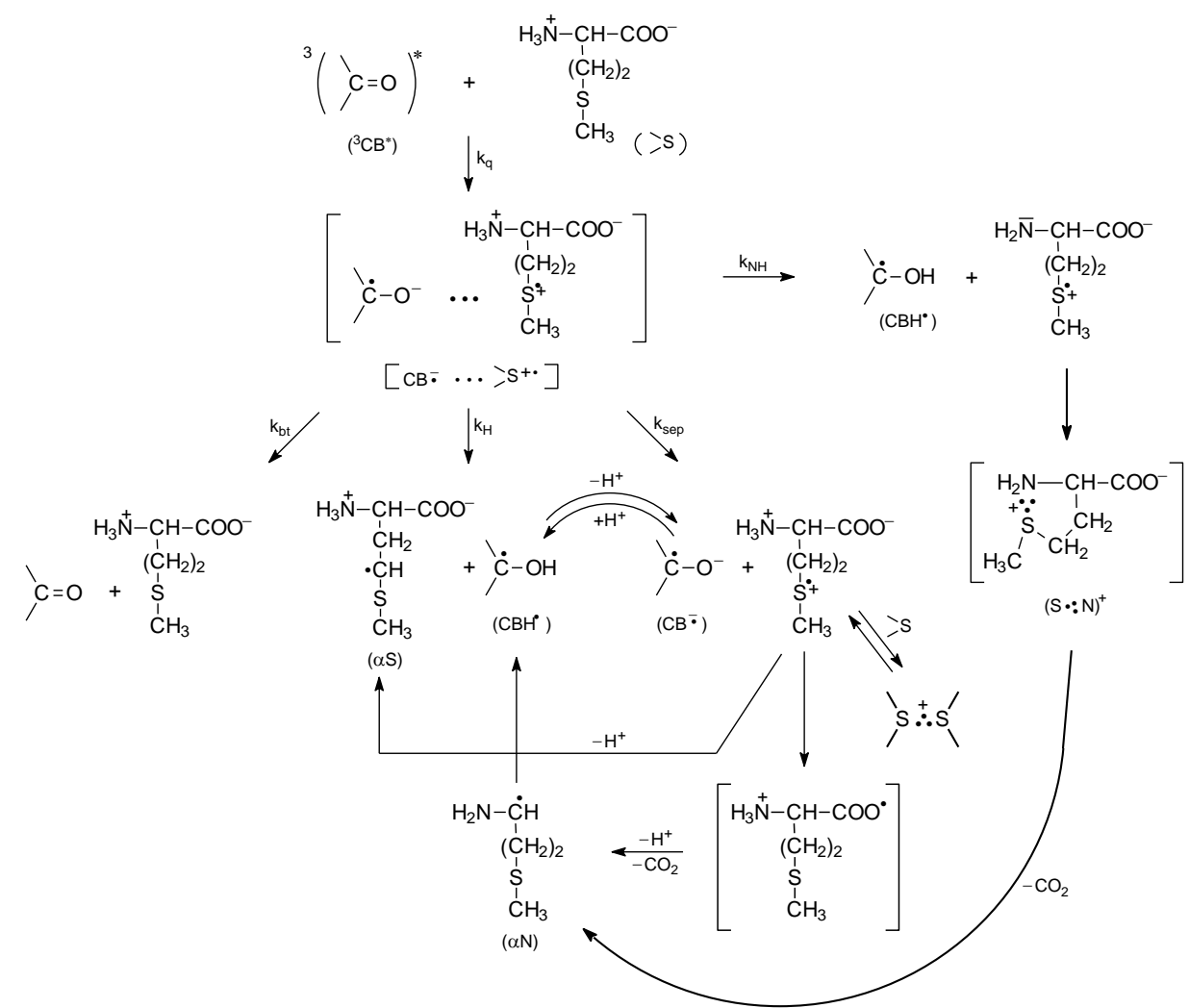

Scheme 6. The mechanism of CB-sensitized photooxidation of methionine in neutral aqueous solutions ( $\mathrm{pH} 7)$. 


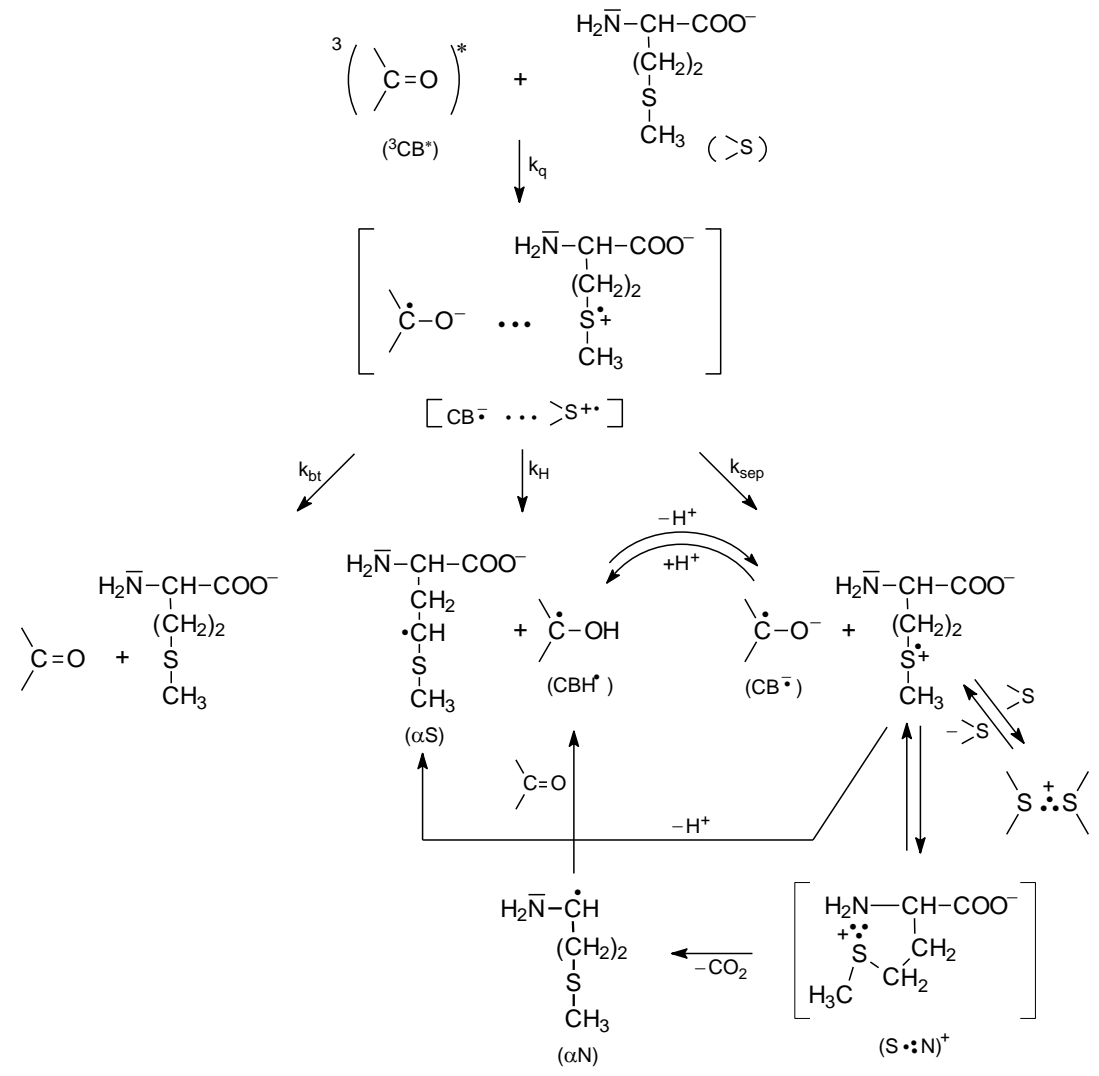

Scheme 7. The mechanism of CB-sensitized photooxidation of methionine in basic aqueous solutions (pH 11).

As presented in Scheme 6 (for methionine with the protonated amino group, $\mathrm{pH} 7$ ), the electron transfer quenching of the CB triplet led to formation of a CT complex $\left[\mathrm{CB}^{\bullet-}\right.$... $>S^{\bullet+}$ ] that can decay in four main primary reactions: (1) charge separation $\left(k_{\mathrm{sep}}\right)$ yielding $\mathrm{CB}^{\bullet-}$ and $>\mathrm{S}^{\bullet+}$ radical ions, (2) proton transfer within the CT complex $\left(k_{\mathrm{H}}\right)$ yielding a ketyl radical $\mathrm{CBH}^{\bullet}$ and an $\alpha$-(alkylthio)alkyl radical $(\alpha \mathrm{S}),(3)$ back electron transfer $\left(k_{\mathrm{bt}}\right)$ leading to regeneration of the reactants in their ground states, and (4) proton transfer from the protonated amino group $\left(-\mathrm{NH}_{3}{ }^{+}\right)$to the $\mathrm{CB}^{\bullet-}$ radical anion within the CT complex $\left(k_{\mathrm{NH}}\right)$ leading to the ketyl radical $\mathrm{CBH}^{\bullet}$ and sulfur-centered radical cation $>\mathrm{S}^{\bullet+}$ with an $-\mathrm{NH}_{2}$ group (unprotonated) yielding a five-membered cyclic two-center three electron-bonded $(\mathrm{S} \cdot \mathrm{N})^{+}$radical cation that can easy decarboxylate to form $\alpha$-aminoalkyl radicals $(\alpha \mathrm{N})$. These short-lived intermediates can undergo further reactions. The $>S^{\bullet+}$ radical cations can be (i) stabilized by formation of three electron bonds with $\mathrm{N}$, or $\mathrm{S}$ atoms (intramolecular $(\mathrm{S} . \mathrm{N})^{+}$and/or intermolecular $(\mathrm{S} \cdot \mathrm{S})^{+}$in the reaction of $>\mathrm{S}^{\bullet+}$ with $>\mathrm{S}$ reactant-methionine), (ii) deprotonated to form $\alpha$-(alkylthio)alkyl radicals $(\alpha S)$, and (iii) decarboxylated to form $\alpha$-aminoalkyl radicals $(\alpha \mathrm{N})$ via pseudo-Kolbe mechanism $[57,58]$. The latter radicals $(\alpha \mathrm{N})$, which in general can be formed in two reaction channels, can be involved in further reactions with the $\mathrm{CB}$ ground state leading to the formation of ketyl radicals and an imine $[15,18,64]$. Evidence for this hypothesis was a secondary growth of $\mathrm{CBH}^{\bullet}$ in neutral or $\mathrm{CB}^{\bullet-}$ in basic solutions that was observed after the $\mathrm{CB}$ triplets had decayed and that was also dependent on the concentration of $\mathrm{CB}$. These observations indicated an additional reaction mechanism for $\mathrm{CB}$ reduction. This interpretation was supported by complementary pulse radiolysis experiments, where $\alpha \mathrm{N}$ radicals were generated and their reaction with the CB in the ground state was studied [15].

The mechanism of photooxidation of methionine in basic aqueous solutions (methionine with a deprotonated amino group) presented in Scheme 7 is similar to the mechanism for neutral solutions (Scheme 6). However, as one would expect, the $k_{\mathrm{NH}}$ reaction is not 
present and the decarboxylation is due to a single reaction channel occurring via a very short-lived $(\mathrm{S}: \mathrm{N})^{+}$radical cations (several ns) (Scheme 7) [67].

The primary intermediates presented in Schemes 6 and 7 were observed directly using time-resolved techniques (that included the kinetics of their formations and decays), e.g., nanosecond laser flash photolysis $[15,18,67]$. The transient absorption spectra obtained in these experiments were resolved at various time delays into the component spectra using a spectral-resolution procedure. This procedure, together with the reference spectra of the expected transients, were described in detail in reference [68]. As a final result of this analysis, the concentrations of all of the transients were determined at various time delays following the laser pulse and were presented as concentration profiles of the transients. Thus, the details of the primary and secondary reactions of CB-sensitized photooxidation of methionine and its derivatives (including formation and decays of intermediates) could be followed by laser flash photolysis techniques. Unfortunately, due to the ground state absorption of the CB sensitizer, the spectral window available for nanosecond laser flash photolysis studies was limited to $\lambda>360 \mathrm{~nm}$. As a consequence, some intermediates, including $\alpha$ S- $\alpha$-(alkylthio)alkyl radical with its maximum absorption at $\lambda=290 \mathrm{~nm}$, could not be observed directly.

Using a relative actinometry method with a $\mathrm{CB}$ solution as an external actinometer (the absorbances at the excitation wavelength of $\mathrm{CB}$ both in the reaction cell and in the actinometer cell, were identical), the initial quantum yields for formation of the intermediates were determined (for experimental details see [68]). The reaction of $\alpha$-aminoalkyl radicals $(\alpha \mathrm{N})$ with the $\mathrm{CB}$ in the ground state led to the slow secondary formation of ketyl radicals $\left(\mathrm{CBH}^{\bullet}\right)$ or ketyl radical anions $\left(\mathrm{CB}^{\bullet-}\right)$ depending on $\mathrm{pH}$ and its efficiency can be described as $\Phi^{\prime \prime} \mathrm{CBH}^{\bullet}$ or $\Phi^{\prime \prime} \mathrm{CB}^{\bullet-}$. The quantum yields measured for aqueous solutions at $\mathrm{pH} \sim 7$ and $\mathrm{pH} \sim 11$ for primary and secondary intermediates are presented in Table 3 .

Table 3. Quantum yields of primary $(\Phi)$ and secondary $\left(\Phi^{\prime \prime}\right)$ intermediates and $\mathrm{CO}_{2}$ in the CBsensitized photooxidation of Met.

\begin{tabular}{|c|c|c|c|c|c|c|c|c|c|}
\hline & $\mathrm{pH}$ & $\boldsymbol{\Phi}_{\mathrm{CBH}}$ & $\boldsymbol{\Phi}_{\mathrm{CB}} \cdot-$ & $\begin{array}{c}\boldsymbol{\Phi}_{\mathrm{CBH}}+ \\
\boldsymbol{\Phi}_{\mathrm{CB}}{ }^{--}\end{array}$ & $\Phi_{(\mathrm{S}: \mathrm{N})}{ }^{+}$ & $\Phi_{(S: . S)}{ }^{+}$ & $\Phi^{\prime \prime} \mathrm{CBH}$ & $\Phi_{\mathrm{CO} 2}-$ & Lit \\
\hline Methionine & 7 & 0.11 & 0.27 & 0.38 & 0 & 0.23 & 0.25 & 0.28 & [18] \\
\hline Methionine & 11 & 0.05 & 0.66 & 0.71 & $0.38^{\text {(a) }}$ & 0.10 & $0.66^{(b)}$ & 0.55 & {$[18,67]$} \\
\hline
\end{tabular}

error $\pm 20 \%$; ${ }^{(a)}$ short-lived transient $\Phi_{(\mathrm{S}: \mathrm{N})}{ }^{+}$, taken at $\sim 20 \mathrm{~ns}$ after the laser pulse; ${ }^{(\mathrm{b})} \Phi^{\prime \prime} \mathrm{CB}^{-}$.

Time-resolved and steady-state studies for the CB-sensitized photooxidation of Met (Table 3) led to the following conclusions regarding the primary photochemical reactions of methionine at neutral $\mathrm{pH}$ (see Scheme 6): (i) the charge separation reaction is an efficient process yielding the ketyl radical anion $\left(\mathrm{CB}^{\bullet-}\right)$ and the sulfur-centered radical cation $>\mathrm{S}^{\bullet+}$ with quantum yield $\Phi_{\mathrm{CB} \bullet-}=0.27$, (ii) $>\mathrm{S}^{\bullet+}$ radical cations can react (reversible reaction) with the excess of methionine in its ground state leading to the intermolecular $(\mathrm{S} \cdot \mathrm{S})^{+}$ dimeric sulfur radical cations with $\Phi_{(S .: S)_{+}}=0.23$, approximately equal to the value of the quantum yield of charge separation $\left(\Phi_{\mathrm{CB} \bullet-}\right)$, (iii) $k_{\mathrm{NH}}$ proton transfer within the CT complex led to ketyl radicals $\mathrm{CBH}^{\bullet}$ and $\mathrm{CO}_{2}$ as final products with quantum yields $\leq 0.11$ $\left(\Phi_{\mathrm{CBH}} \bullet\right.$ ), (iv) decarboxylation reaction $>\mathrm{S}^{\bullet+}$ radicals via pseudo-Kolbe reaction $[57,58]$ cannot be neglected.

In the case of methionine in basic solutions (Scheme 7), the main primary reaction is the charge separation reaction (with $\Phi_{\mathrm{CB} \bullet-}=0.66$ twice that for neutral $\mathrm{pH}$ ) and the $k_{\mathrm{H}}$ primary reaction is more than ten times less efficient than $k_{\text {sep }}$ reaction. Moreover, the intermolecular $(S: S)^{+}$intermediate is present along with an efficient decarboxylation $\left(\Phi_{\mathrm{CO} 2}=0.55\right)$ occurring via a very short-lived intramolecular $(\mathrm{S}: \mathrm{N})^{+}$radical cation (ns time scale).

As shown in Table 3, the quantum yields for secondary reactions at $\mathrm{pH} 7$ and $\mathrm{pH} 11$ $\left(\Phi^{\prime \prime}{ }_{\mathrm{CBH}} \bullet\right.$ or $\left.\Phi^{\prime \prime}{ }_{\mathrm{CB} \bullet-}\right)$ are equal within the experimental errors with quantum yields of decarboxylation $\left(\Phi_{\mathrm{CO} 2}=0.28\right.$ or $\Phi_{\mathrm{CO} 2}=0.55$, respectively). However, the mechanism for 
the slow formation of the ketyl radical anion $\mathrm{CB}^{\bullet-}$ in the secondary reactions was shown to be very complex (e.g., $\Phi_{\mathrm{CB} \bullet-}$ was $\mathrm{pH}$ dependent and decrease for $\mathrm{pH}$ above 11 and at $\mathrm{pH}$ 13.2 was approaching zero). This was explained by the involvement of additional acid-base equilibria for sulfur- and nitrogen-centered radical cations, see reference [67].

In addition to the time-resolved kinetic studies using nanosecond laser flash photolysis, the mechanistic conclusions, which are presented in Schemes 6 and 7 for methionine, timeresolved CIDNP, and ESR techniques, have expanded our mechanistic understanding of radical reaction pathways of the Met side chain in various local environments containing differing functional groups. The CIDNP study performed by Goez et al. [23,69] for CBsensitized photooxidation of methionine confirmed the presence of an electron transfer mechanism involving the sulfur atom (not the nitrogen atom) as the electron donor. The formation of a two-center three electron bonded radical cation $(\mathrm{S}: \mathrm{N})^{+}$in alkaline solutions $(\mathrm{pH}=12)$ and the presence of the monomeric sulfur-centered radical cation $>\mathrm{S}^{\bullet+}$ in neutral solution $(\mathrm{pH}=6)$ were also proved.

A time-resolved ESR spectroscopy study by Yashiro et al. [26] for anthraquinonesulfonate sensitized photooxidation of methionine in aqueous solution led to the following conclusions: at low $\mathrm{pH}$ the intermolecular dimeric sulfur radical cation $\left(\mathrm{S} \cdot \mathrm{SS}^{+}\right.$was the main intermediate but at high $\mathrm{pH}$, deprotonation of a monomeric sulfur-centered radical cation $>\mathrm{S}^{\bullet+}$ to form the aminyl radical $\left(\mathrm{CH}_{3}-\mathrm{S}-\mathrm{CH}_{2}-\mathrm{CH}_{2}-\mathrm{CH}-(\mathrm{COO}-)-\mathrm{N} \bullet \mathrm{H}\right)$ was suggested as the main reaction channel. However, the $\alpha$-(alkylthio)alkyl radicals $(\alpha S)$ were not detected in their ESR experiments.

Some differences in the description of the mechanisms and main intermediates were observed for Met at high pH i the results of ESR by Yashiro et al. [26] and the nanosecond laser flash photolysis studies could be due to differences (i) in the sensitizers used in these two types of experiments (anthraquinone sulfonate (AQS) vs. 4-carboxybenzophenone (CB)) and (ii) in the experimental conditions (e.g., laser pulse energies $90 \mathrm{~mJ}$ in comparison with 1-6 mJ, respectively). This may lead to differences in the decay channels of the respective CT complexes [Sens ${ }^{\bullet-} \ldots>S^{\bullet+}$ ] with AQS and CB as sensitizers. Moreover, the spectral window available in the nanosecond laser flash photolysis did not allow detection of aminyl radical $\left(\mathrm{CH}_{3}-\mathrm{S}-\mathrm{CH}_{2}-\mathrm{CH}_{2}-\mathrm{CH}-(\mathrm{COO}-)-\mathrm{N} \bullet \mathrm{H}\right)$ observed in the EPR experiments. Furthermore, as was presented by Bonifačić et al. [70] that type of radicals can undergo further transformation via 1,2-H shift to $\alpha$-C-centered radicals. On the other hand, identification of radical-radical coupling products such as $\alpha \mathrm{S}-\alpha \mathrm{S}$ in the steady-state photooxidation of Met derivatives sensitized by CB [22,59] confirmed the presence of $\alpha \mathrm{S}$ radicals in the reaction mechanisms.

The mechanism for the photooxidation of methionine was also studied using sensitizers different from $\mathrm{CB}$, namely N-(Methylpurin-6-yl)pyridinium cation $\left(\mathrm{Pyr}^{+}\right)$in aqueous solution at neutral $\mathrm{pH}$ [71]. It was shown by nanosecond laser flash photolysis and steadystate photolysis studies that the mechanism of photooxidation is, in general, similar to that for CB-sensitized photooxidation of methionine at pH 7 [15]. The quenching of $\mathrm{Pyr}^{+}$ excited triplet state led to the decay of the CT complex $\left[\mathrm{Pyr}^{\bullet} \ldots>\mathrm{S}^{\bullet+}\right]$ in two primary reactions: (i) charge separation to a $\mathrm{Pyr}^{\bullet}$ radical and an $>\mathrm{S}^{\bullet+}$ radical cation and (ii) back electron transfer to regenerate reactants in their ground states. The reactions of the resulting sulfur-centered radical cation $>S^{\bullet+}$ are similar to those seen in CB-sensitization (see Scheme 6). These radical cations can undergo decarboxylation yielding an $\alpha$-aminoalkyl radical $(\alpha \mathrm{N})$ that can reduce $\mathrm{Pyr}^{+}$cations to additional $\mathrm{Pyr}^{\bullet}$ radicals (slow secondary growth of $\mathrm{Pyr}^{\bullet}$ ) and formation of intermolecular $(\mathrm{S} \cdot: \mathrm{S})^{+}$dimeric sulfur radical cations in reaction to methionine in its ground state. The time-resolved and steady-state studies led to a detailed quantitative description of the primary and secondary reactions for methionine and other sulfur-containing amino acids [71].

\subsubsection{Methionine Derivatives}

In this subsection, the methionine derivatives, the methyl ester of $\mathrm{N}$-acetyl-methionine $\left(\mathrm{N}-\mathrm{Ac}-\mathrm{Met}-\mathrm{OCH}_{3}\right)$ and the $\mathrm{N}$-methylated amide of $\mathrm{N}$-acetyl-methionine $\left(\mathrm{N}-\mathrm{Ac}-\mathrm{Met}-\mathrm{NHCH}_{3}\right)$ 
were selected as simple models of a Met residue incorporated into the interior of oligopeptides and proteins (Scheme 8).

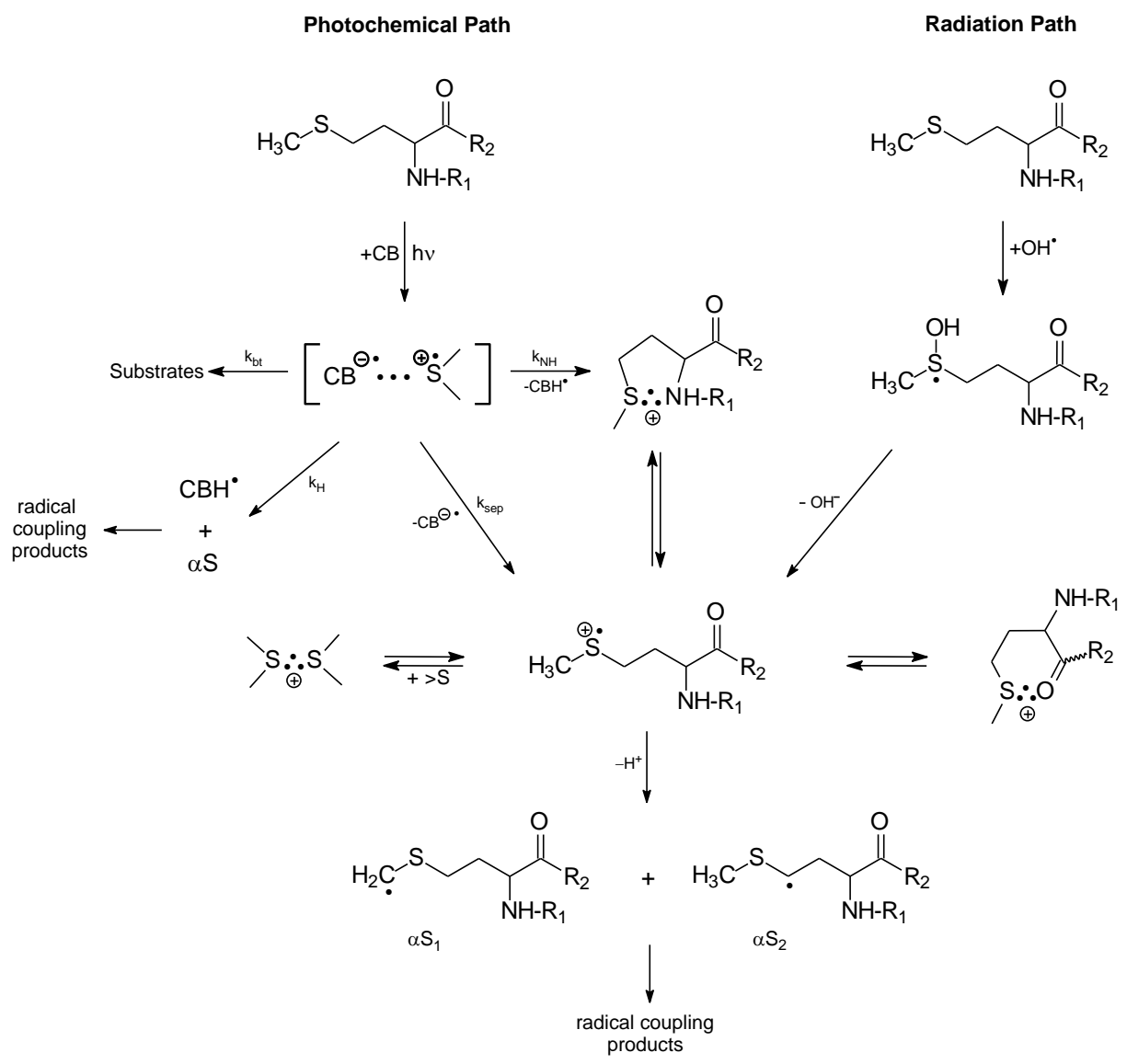

Scheme 8. The mechanism of CB-sensitized photo- and radiation-induced oxidation of methionine derivatives in aqueous solutions $\left(\mathrm{R}_{1}\right.$ denotes $\mathrm{N}$-Ac- group or $\mathrm{H}-$ and $\mathrm{R}_{2}$ denotes $-\mathrm{OCH}_{3},-\mathrm{NH}_{2}$ and $\mathrm{NHCH}_{3}$ groups).

The purpose for acetylating the N-terminal amino group was to eliminate the fast intramolecular proton transfer from the amino group to the $>\mathrm{S}$. $\mathrm{OH}$ moiety (see Section 2.1.2). A similar purpose for acetylating the $\mathrm{N}$-terminal amino group applies to the $\mathrm{CB}$-sensitized photooxidation of Met. In this case, fast intramolecular proton transfer from the N-terminal amino group of Met to the ketyl radical anion $\left(\mathrm{CB}^{\bullet-}\right)$ within the $\left[\mathrm{CB}^{\bullet-} \ldots>\mathrm{S}^{\bullet+}\right]$ complex [19], (see $k_{\mathrm{NH}}$ reaction channel, in Scheme 6) is eliminated. On the other hand, esterification of the $\mathrm{C}$-terminal carboxyl group or amidation by the $\mathrm{N}$-methylated amide group $\left(-\mathrm{NHCH}_{3}\right)$ eliminates decarboxylation of Met residue via the pseudo-Kolbe mechanism $[57,58]$. Therefore, the use of N-Ac-Met-OCH 3 or N-Ac-Met- $\mathrm{NHCH}_{3}$ has the following benefit: it allows one to mimic and prove the mechanisms for primary and secondary radical reactions following oxidation of the Met residue with no contribution of $\mathrm{N}$ - and C-terminal functional groups.

The results of intensive studies for photo- and radiation-induced oxidation of methionine derivatives (with blocked amino and carboxylic groups) by the complementary laser flash photolysis and pulse radiolysis techniques are summarized in Scheme 8, showing primary photo- and radiation-induced processes.

As presented in Scheme 8, both the photochemical and radiation pathways led to the formation of one common intermediate, namely the sulfur-centered radical cation $\left(>S^{\bullet+}\right)$. In the case of photochemical pathway the formation of $\left(>S^{\bullet+}\right)$ is occurring via one of the four competing primary reactions of $\mathrm{CT}$ complex, namely the charge separation reaction of $\left[\mathrm{CB}^{\bullet-} \ldots>\mathrm{S}^{\bullet+}\right]$. For the radiation pathway, a main channel leading to $\left(>\mathrm{S}^{\bullet+}\right)$ is the 
$\mathrm{HO}^{-}$release from the MetS: $: \mathrm{OH}$ adduct. These pathways exemplify neighboring group participation in the reactions of two intermediates, the sulfur radical cations $\left(>S^{\bullet+}\right)$ and MetS. :OH during Met oxidation (see Scheme 8) [37]. As was mentioned in the previous sections, two-centered, three electron (2c-3e) bonds between the oxidized sulfur atom and the lone electron pairs located on the nitrogen atom in the $\mathrm{N}$-terminal amino group and the oxygen atoms in the C-terminal carboxyl group are responsible for stabilization of $>S^{\bullet+}$. Such stabilization leads to five-membered intramolecularly $S$ : :N-bonded species and/or sixmembered intramolecularly S: O-bonded species [8,9,16-19]. Subsequent studies showed that heteroatoms present in the peptide bond can be also involved in the formation of similar transient species with 2c-3e bonds with the oxidized sulfur atom [11-13,72-74].

The secondary reactions of intermediates shown in Scheme 8 led to formation of various stable products. According to our knowledge, there were only two attempts to identify stable products after $\mathrm{HO}^{\bullet}$ or CB-induced oxidation of methionine derivatives $[22,59]$. They addressed the full mechanism of Met oxidation from the initial step (hv excitation or radiolysis) via identification of short-lived intermediates (by time-resolved techniques) to the analysis of stable products (in steady-state UV irradiation or $\gamma$-radiolysis). Knowledge of the structure of stable products was a strong argument confirming the assignments of intermediates detected in the time-resolved experiments.

Quantum yields of primary intermediates in the CB-sensitized photooxidation of Met derivatives are summarized in Table 4 . In the case of methionine derivatives with a blocked carboxylic group $\left(\mathrm{MetOCH}_{3}\right.$ and $\left.\mathrm{MetNH}_{2}\right)(\mathrm{S} \cdot \mathrm{N})^{+}$was the main primary intermediate regardless of $\mathrm{pH}$ values. At low $\mathrm{pH}$, where amino group is protonated (see Figure 1), the presence of the $(\mathrm{S}: \mathrm{N})^{+}$radical cation can be rationalized via the $\mathrm{k}_{\mathrm{NH}}$ reaction (Scheme 8 ). For N-Ac-Met: (i) the charge separation reaction $\left(\mathrm{k}_{\mathrm{sep}}\right)$ is the main reaction of the CT complex $\left[\mathrm{CB}^{-} \ldots>\mathrm{S}^{+}\right]$decay, (ii) the decarboxylation reaction can be neglected and (iii) the intermolecular dimeric sulfur radical cation $(\mathrm{S} \cdot \mathrm{S})^{+}$is the main intermediate. For methionine derivatives with blocked amino and carboxylic groups (N-Ac-Met- $\mathrm{OCH}_{3}, \mathrm{~N}-\mathrm{Ac}-$ Met- $\mathrm{NHCH}_{3}$ and $\left.\mathrm{N}-\mathrm{Ac}-\mathrm{Met}-\mathrm{NH}_{2}\right)$, the proton transfer within the $\mathrm{CT}$ complex $\left(\mathrm{k}_{\mathrm{H}}\right)$ yielding ketyl radical $\mathrm{CBH}^{-}$and $\alpha$-(alkylthio)alkyl radical $(\alpha \mathrm{S})$ was found to be the dominate primary reaction over the charge separation reaction $\left(\mathrm{k}_{\mathrm{sep}}\right)$ that yielded only a small amount of $\mathrm{CB}^{--}$and $(\mathrm{S} \cdot: \mathrm{S})^{+}$dimer. The presence of these intermediates was confirmed by the analysis of stable products formed during the steady-state photolysis. The main stable products were found to be the combination products of ketyl radicals with $\alpha$-(alkylthio)alkyl radical $(\alpha \mathrm{S}-\mathrm{CBH}$ stable products) [22,59].

Table 4. Quantum yields of primary intermediates and $\mathrm{CO}_{2}$ in the $\mathrm{CB}$-sensitized photooxidation of Met derivatives.

\begin{tabular}{|c|c|c|c|c|c|c|c|c|}
\hline Met Derivatives & $\mathrm{pH}$ & $\Phi_{\mathrm{CBH}}$ & $\boldsymbol{\Phi}_{\mathrm{CB}} \cdot-$ & $\begin{array}{l}\Phi_{\mathrm{CBH}}+ \\
\Phi_{\mathrm{CB}}-\end{array}$ & $\Phi_{(\mathrm{S}: \mathrm{N})}{ }^{+}$ & $\Phi_{(\mathrm{S}: \mathrm{S})^{+}}$ & $\Phi_{\mathrm{CO}_{2}-}-$ & Lit \\
\hline Met- $\mathrm{OCH}_{3}$ & 6 & 0.39 & 0 & 0.39 & 0.20 & 0.04 & 0 & {$[19,75]$} \\
\hline Met-OCH $\mathrm{OH}_{3}$ & 10 & 0 & 0.43 & 0.43 & 0.28 & 0.04 & 0 & {$[19,75]$} \\
\hline Met- $\mathrm{NH}_{2}$ & 5 & 0.39 & 0 & 0.39 & 0.28 & 0.10 & 0 & {$[19,75]$} \\
\hline Met- $\mathrm{NH}_{2}$ & 10 & 0 & 0.48 & 0.48 & 0.12 & 0.07 & 0 & [19] \\
\hline N-Ac-Met & 7 & 0.12 & 0.29 & 0.41 & 0 & 0.28 & 0.05 & {$[18,19]$} \\
\hline N-Ac-Met & 10 & 0.13 & 0.29 & 0.42 & 0 & 0.27 & - & {$[19,75]$} \\
\hline N-Ac-Met-OCH 3 & 6 & 0.22 & 0.04 & 0.26 & $<0.05$ & 0.07 & 0 & [19] \\
\hline N-Ac-Met-NH ${ }_{2}$ & 6 & 0.19 & 0.07 & 0.26 & 0 & 0.09 & 0 & [19] \\
\hline $\begin{array}{l}\text { N-Ac-Met- } \\
\mathrm{NHCH}_{3}\end{array}$ & 7 & 0.32 & $<0.02$ & 0.34 & 0 & 0 & 0 & [22] \\
\hline
\end{tabular}

errors $\pm(10-20) \%$.

An additional argument for a mechanism of the proton transfer reaction within the CT complex $\left(\mathrm{k}_{\mathrm{H}}\right)$ for methionine derivatives with substituted amino and carboxylic groups came from the photochemical study of benzophenone-methionine dyads (diketopiperazinebased BP-Met) in acetonitrile solutions [76]. Both the time-resolved laser flash photolysis 
experiments and the steady-state irradiations of sterically constrained BP-Met dyads identified an electron transfer process from the sulfur atom to the BP triplet followed by proton transfer to form biradical (with quantum yields in the range of 0.6 ). This biradical was a major precursor of a cyclic stable product (an analogous product to $\alpha \mathrm{S}-\mathrm{CBH}$ observed in the photolysis of N-Ac-MetOCH${ }_{3}$ and N-Ac-MetNHCH 3 ).

\section{Methionine in Linear Peptides}

\subsection{Radiation-Induced Oxidation}

\subsubsection{Methionine as the N/C-Terminal Amino Acid Residue}

The location of the Met residue in the linear peptide structure was found to affect the type of intermediates formed during ${ }^{\bullet} \mathrm{OH}$-induced oxidation. This was demonstrated for simple dipeptides containing Met with the reversed sequence of amino acids: Met-Gly/GlyMet and Met-Leu/Leu-Met [8,77]. For Met-Gly and Met-Leu dipeptides the observed transient absorption bands in the $\mathrm{pH}$ range 5-6 with $\lambda_{\max }=290$ and $390 \mathrm{~nm}$ were respectively assigned to $\alpha$-S1/ $\alpha$-S2 radicals derived from Met and $\operatorname{Met}(\mathrm{S} \cdot \mathrm{N})^{+}$radical cations. Thus, the location of Met residue as the N-terminal amino acid does not significantly change the primary radical reactions related to the oxidation process (see Scheme 1), except for the fact that the decarboxylation process involving the intra-molecular $\operatorname{Met}(\mathrm{S}: \mathrm{N})^{+}$is inhibited, although the carboxyl group in C-terminal Gly or Leu residues is not protected. This is reflected in a much longer lifetime $\left(\tau_{1 / 2} \sim 200-400 \mu \mathrm{s}\right)$ of these radical cations and lack of presence of $\mathrm{CO}_{2}$ in the system containing Met-Gly [57]. Interestingly, in the presence of superoxide radical anion $\left(\mathrm{O}_{2}{ }^{\bullet-}\right)$ this species decays much faster with the rate constant $\mathrm{k}\left(\operatorname{Met}(\mathrm{S} \cdot \mathrm{N})^{+}+\mathrm{O}_{2}^{\bullet-}\right)=5.3 \times 10^{9} \mathrm{M}^{-1} \mathrm{~s}^{-1}$ [78]. It is important to note that the reaction of $\mathrm{O}_{2}{ }^{\bullet-}$ with superoxide dismutase (SOD) with the respective $\mathrm{k}=2.3 \times 10^{9} \mathrm{M}^{-1} \mathrm{~s}^{-1}$ proceeds ca. 2.5-fold slower than its reaction with $\operatorname{Met}(\mathrm{S} \cdot \mathrm{N})^{+}$[79]. From biological point of view it means that reaction of $\operatorname{Met}(\mathrm{S} \cdot \mathrm{N})^{+}$with $\mathrm{O}_{2}{ }^{\bullet-}$ is a potential source for methionine sulfoxide formation when the system is exposed to high concentration of reactive oxygen species (ROS).

On the other hand, for Gly-Met and Leu-Met dipeptides, the observed transient absorption spectrum in the same $\mathrm{pH}$ range is dominated by the absorption band with $\lambda_{\max }=290 \mathrm{~nm}$ and a clearly pronounced shoulder in the 360-400 $\mathrm{nm}$ range. These absorption bands were assigned to $\alpha$-S1/ $\alpha$-S2 radicals derived from Met and $\operatorname{Met}(\mathrm{S} \cdot \mathrm{O})^{+}$radical cation, respectively. Taking into account the character of intermediates and final products detected during ${ }^{\bullet} \mathrm{OH}$-induced oxidation of dipeptides containing serine, threonine and $\gamma$-glutamic acid as the N-terminal amino acids (see Schemes 9 and 10), it is reasonable to assume that fast intramolecular proton transfer from the free amino group $\left(\mathrm{NH}_{3}{ }^{+}\right)$of the dipeptide to the MetS: OH moiety occurs also for dipeptides containing amino acids with alkyl side groups. The sulfur monomeric radical cation $\left(\mathrm{Met}^{\bullet+}\right)$ resulting from this reaction can decay along three different pathways: (i) forming the very-short-lived multimembered S: N-bonded radical cation which can be the precursor of C-centered radicals (on the $\alpha-\mathrm{C}$ atom of the Gly residue) formed via analogous consecutive reactions presented in Scheme 11, (ii) forming the $\operatorname{Met}(\mathrm{S}: \mathrm{O})^{+}$radical cation, (iii) undergoing decarboxylation via the pseudo-Kolbe mechanism to form substituted $\alpha-\mathrm{N}$ radicals on the Met residue confirmed by detection of $\mathrm{CO}_{2}$ [57].

The first convincing evidence for intramolecular proton transfer from the free amino group $\left(\mathrm{NH}_{3}{ }^{+}\right)$of the dipeptide to the MetS: $\mathrm{OH}$ moiety and formation of the multimembered S. N-bonded radical cation was obtained from the studies of $\bullet \mathrm{OH}$-induced oxidation of Ser-Met and Thr-Met dipeptides [14]. The general reaction scheme involves an intramolecular proton transfer from the protonated N-terminal amino group to an initially formed MetS: $\mathrm{OH}$ radical on the Met residue. The MetS. $\mathrm{OH}$ undergoes subsequently elimination of water and formation of a $\operatorname{Met}(\mathrm{S} . \mathrm{N})^{+}$intermediate which was characterized by pulse radiolysis and has a lifetime $\left(\tau_{1 / 2)} \approx 300 \mathrm{~ns}\right)$. This intermediate exists in an equilibrium with the open chain $\mathrm{N}$-centered radical cation which further undergoes efficient heterolytic bond cleavage of the $C_{\alpha}-C_{\beta}$ bond of the Ser or Thr side chain, leading to an 
$\alpha$-aminoalkyl radical of the structure $\mathrm{H}_{2} \mathrm{~N}-\mathrm{C} \cdot \mathrm{H}-\mathrm{C}(=\mathrm{O})-\mathrm{NH}$-peptide (identified by timeresolved ESR spectroscopy) and formaldehyde or acetaldehyde, respectively (Scheme 9).

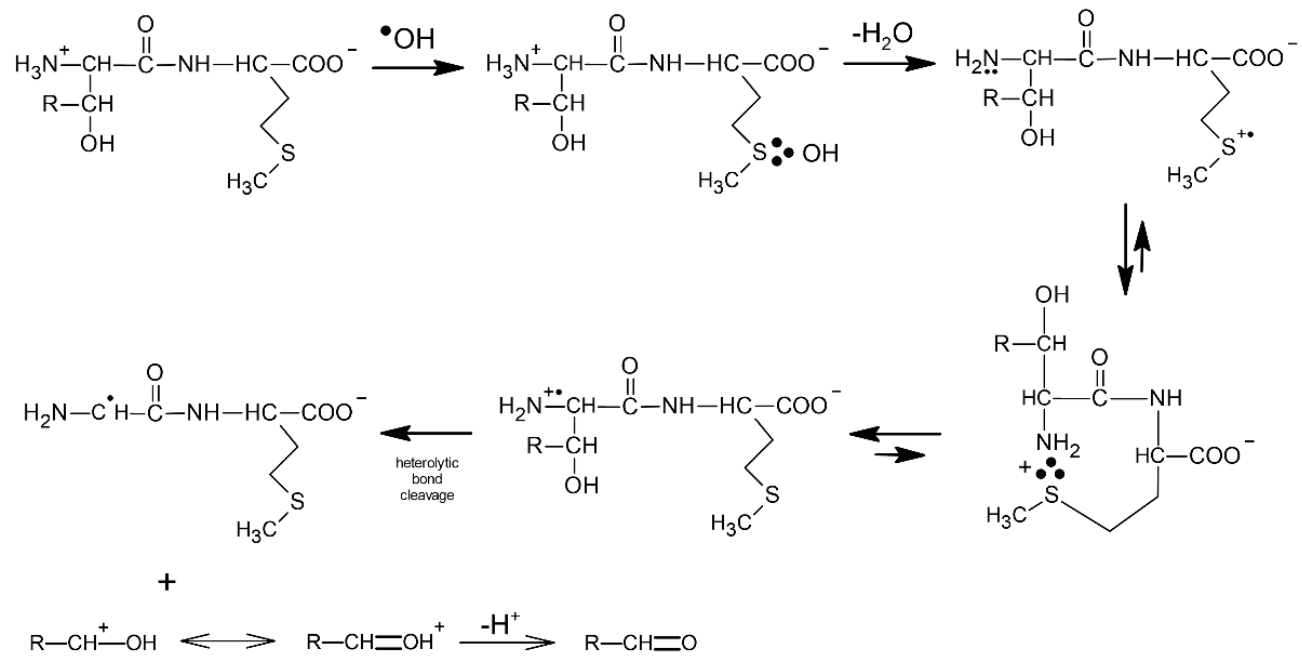

Scheme 9. General reaction scheme for ${ }^{\bullet} \mathrm{OH}$-induced oxidation of methionine in Ser-Met and Thr-Met dipeptides ( $\mathrm{R}=\mathrm{H}$ for serine, $\mathrm{R}=\mathrm{CH}_{3}$ for threonine).

The above mechanism illustrates an interesting feature which has to be considered in any studies on oxidation of peptides containing Met. Although, based on the respective rate constants, Met is the main target of ${ }^{\bullet} \mathrm{OH}$ radicals attack, the major final product contains fragments of either Ser or Thr residues. Such transfer of damage constitutes an important mechanistic pathway frequently observed during oxidation of peptides and proteins.

Further evidence of proton transfer from the free amino group of the peptide to the MetS.. $\mathrm{OH}$ moiety and formation of the multi-membered $\mathrm{S} \cdot \mathrm{N}$-bonded radical cation was obtained from studies of ${ }^{\bullet} \mathrm{OH}$-induced oxidation of the $\gamma$-Glu-Met dipeptide [80]. The mechanism is in principle very similar to that presented for Ser-Met and Thr-Met except for the fact that the open chain $\mathrm{N}$-centered radical cation via establishment of the mesomeric form $\left(\mathrm{H}_{2} \mathrm{~N}-\mathrm{CH}\right.$-(COO$\left.\left.{ }^{\bullet}\right)\right)$-peptide and subsequent $\alpha$-fragmentation leads to $\alpha$-aminoalkyl type radicals and $\mathrm{CO}_{2}$ (Scheme 10$)$.

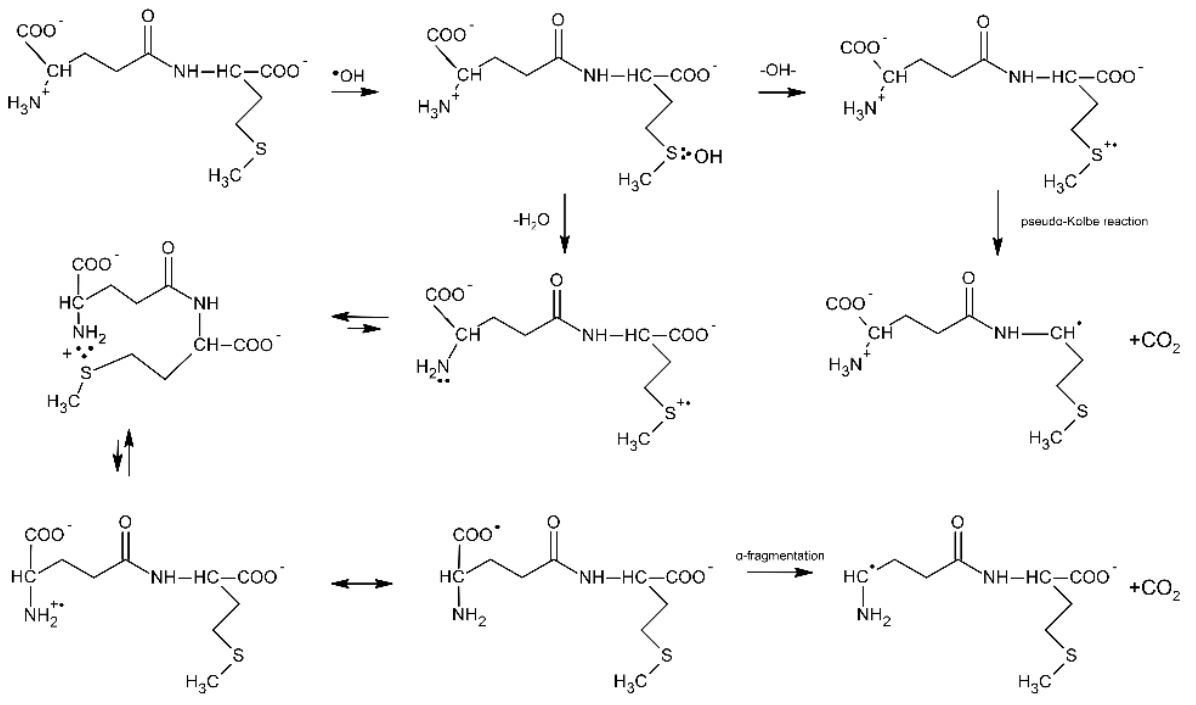

Scheme 10. General reaction scheme for ${ }^{\bullet} \mathrm{OH}$-induced oxidation of methionine in $\gamma$-Glu-Met dipeptide. 
These radicals obtained from the N-terminal decarboxylation reaction can be easily probed via their reaction with p-nitroacetophenone (PNAP) leading to PNAP ${ }^{\bullet-}$ radical anion [80-82]. The following fact should be emphasized at this point: the radiation chemical yield of $\mathrm{CO}_{2}$ measured for this dipeptide was not equal to the radiation chemical yield of $\alpha$-aminoalkyl type radicals [80]. This implies that decarboxylation must proceed via two different routes, namely via the $\operatorname{Met}(\mathrm{S}: \mathrm{N})^{+}$intermediate and via a pseudo-Kolbe reaction. This finding differs from $X-$ Met peptides ( $\mathrm{X}=\mathrm{Gly}$, Ala, Val, Leu) where decarboxylation was found to occur exclusively via the latter mechanism [57]. Insertion of a Gly residue between the $\gamma$-Glu and Met residues in $\gamma$-Glu-Gly-Met-Gly peptide increases the separation distance through the bonds as compared with $\gamma$-Glu-Met; however, it does not affect the radiation chemical yield of $\alpha$-aminoalkyl type radicals $G(\alpha-N)$ [81]. This implies that the yields of multi-membered $S:$ N-bonded radical cations $G(S \cdot: N)^{+}$have to be similar, which at the same time means that the rate of end-to-end contact formation is similar in both peptides. In other words, the peptide backbone in $\gamma$-Glu-Gly-Met-Gly is flexible enough to allow direct interaction between amine and sulfur moieties. The $\gamma$-Glu-(Pro $)_{n}-$ Met $(n=0-3)$ oligopeptides were chosen as oligopeptides with restricted conformational flexibility [82]. The observed continuous decrease of $G(\alpha N)$ with the number of Pro residues (from 0 to 3 ) indicates that formation of a contact between the $\mathrm{S}$-atom in the C-terminal Met residue and the $\mathrm{N}$-atom of a deprotonated N-terminal amino group of Glu is controlled by the relative diffusion of the $S^{\bullet+}$ and unoxidized $\mathrm{N}$-atom. This study clearly shows that a remote amino group that served as both a proton and a free electron pair donor and that is separated from the Met residue by an oligoproline rigid backbone can still affect the chemistry on Met.

It also worth mentioning that neighboring amino acids (such as tyrosine or tryptophan) can affect the chemistry on Met. Taking into account their respective reduction potentials $\left(\mathrm{E}^{0}\left(\operatorname{TrpN} \mathrm{N}^{\bullet} \operatorname{TrpN}\right)=+1.015 \mathrm{~V}\right.$ vs. NHE at $\left.\mathrm{pH} 7\right)[83], \mathrm{E}^{0}\left(\mathrm{TyrO}^{\bullet}, \mathrm{H}^{+} / \mathrm{TyrOH}=+0.93 \mathrm{~V}\right.$ vs. $\mathrm{NHE}$ at $\mathrm{pH} 7$ ) [84] and $\mathrm{E}^{0}\left(\mathrm{MetS}: \mathrm{OH} / \mathrm{Met}_{1} \mathrm{HO}^{-}\right)=+1.43 \mathrm{~V}$ vs. NHE, $\mathrm{E}^{0}\left(\mathrm{MetS}^{\bullet+} / \mathrm{MetS}\right)=1.66 \mathrm{~V}$ vs. NHE [85], they can be easily oxidized by the monomeric sulfur radicals MetS ${ }^{\bullet+}$ or MetS. $\mathrm{OH}$ adducts. This phenomenon was nicely illustrated with the example of Met-enkephalin. Met-enkephalin (Met-enk), is a part of a mixture with Leu-Enk and is present in the central nervous system. Met-enk is a pentapeptide: Tyr-Gly-Gly-Phe-Met and is produced while an organism is under mental and/or physical stress [86]. The degradation induced by ${ }^{\bullet} \mathrm{OH}$ radicals in Met-enk is also relevant to the disorders in inflammatory processes.

Nanosecond pulse radiolysis was used to elucidate the oxidation mechanisms of Met-enk by ${ }^{\bullet} \mathrm{OH}$ radicals [87]. Based on the respective rate constants of Tyr, Phe, and Met residues with $\bullet \mathrm{OH}$ radicals [88], formation of $\mathrm{OH}$ adducts on both aromatic (Tyr, Phe) and Met residues is reasonable and expected. Interestingly, fast formation of $\mathrm{OH}$ adducts on Tyr and Phe residues was confirmed by pulse radiolysis; however, no transient which can be assigned to MetS. $\mathrm{OH}$ was observed. Moreover, the fast formation of the transient spectrum assigned to $\mathrm{TyrO}^{\bullet}$ radicals was also observed. For a comparison, the absorption spectra of transients derived from Leu-enk (the C-terminal Met is replaced by Leu) were recorded and assigned only to the formation of $\mathrm{OH}$ adducts on Tyr and Phe residues. These differences in absorption spectra led to the hypothesis that $\mathrm{TyrO}^{\bullet}$ radicals are formed through a new process not present in Leu-enk, i.e., an intramolecular electron transfer (IET) involving a MetS.. $\mathrm{OH}$ intermediate and a Tyr residue. The lower limit for the rate constant of IET was found to be $1.2 \times 10^{7} \mathrm{~s}^{-1}$. The high value for the rate constant for IET in Met-enk is consistent with the lack of $\alpha$-(alkylthio)alkyl radicals and with the lack of $\mathrm{CO}_{2}$ formation [57]. Depending on the $\mathrm{pH}$, the former radicals might be potentially produced by the competitive deprotonation of either MetS. OH or MetS ${ }^{\bullet+}$. In turn, the formation of $\mathrm{CO}_{2}$ would have resulted from the competitive oxidation of the carboxylate function in Met via a pseudo Kolbe mechanism. Similar oxidation studies of Met-enk were performed using $\mathrm{Br}_{2}{ }^{\bullet-}$ as a selective one-electron oxidant. They allowed for the determination of the first order rate constant of an IET involving MetS. $\mathrm{Br}$ and Tyr residues $\left(\mathrm{k}=1.1 \times 10^{5} \mathrm{~s}^{-1}\right)$ [89]. On the other hand, the rate constant for IET between MetS. $\mathrm{Br}$ and Tyr residues in Tyr-(Pro) 3 -Met (a peptide with the same number (3) of amino acid residues 
between Tyr and Met residues as in Met-enk) was found to decrease 10-fold and be equal to $1.1 \times 10^{4} \mathrm{~s}^{-1}$ [90]. In the latter case an IET is likely partitioning along the peptide backbone and direct water mediated contacts between side chains of terminal amino acids residues (Tyr and Met). Therefore, in Met-enk, an IET occurs most probably rather through space (water) pathway with a possible involvement of $\mathrm{H}$-bonds shortcuts. This conclusion is consistent with computational conformational analysis of this pentapeptide [91]. At the end of these considerations, it has to be stressed that the possibility for fast IET between an oxidized Met residue and the easily oxidized Tyr and Trp residues may lead to repairing of Met oxidative damage, along with the formation of damage in other sites of a peptide or protein molecule.

\subsubsection{Methionine as the Internal Amino Acid Residue}

The Gly-Met-Gly peptide is the simplest model peptide where the Met residue is not a terminal amino acid. Therefore, this peptide can serve as the model of Met residues incorporated in the interior of oligopeptides and proteins. The reaction of ${ }^{\bullet} \mathrm{OH}$ radicals with Gly-Met-Gly and its $\mathrm{N}$-acetyl derivative were studied by pulse radiolysis [74]. The transient absorption spectra recorded at short times after the pulse in $\mathrm{N}_{2} \mathrm{O}$-saturated aqueous solutions at $\mathrm{pH} 5.5$ were characterized by a strong UV absorption band with $\lambda_{\max }=270 \mathrm{~nm}$ and a very weak and broad shoulder in the range of $400-500 \mathrm{~nm}$. Spectral resolutions of these spectra were necessary in order to resolve them into contributions from various intermediates: the $\alpha$-C-centered radicals on Met residues $(\alpha-C)$, the $\alpha$-aminoalkyl radicals $(\alpha-\mathrm{N})$, the $\alpha$-(alkylthio)alkyl radicals $(\alpha-\mathrm{S})$, the intramolecular $\operatorname{Met}(\mathrm{S} \cdot \cdot \mathrm{N})^{+}$radical cations and the intermolecular Met(S. $\cdot S)^{+}$radical cations. Their radiation chemical yields and percentage contribution (in parenthesis) to the total yield of radicals formed in the reaction of $\mathrm{OH}$ is listed in Table 5.

Table 5. The radiation chemical yield $(G){ }^{(a)}$ of radicals and radical cations and their percentage contribution (in parenthesis) to the total yield of radicals formed in the reaction of ${ }^{\bullet} \mathrm{OH}$ radicals with Gly-Met-Gly $^{(b)}$ [74].

\begin{tabular}{cccccc}
\hline Time & $\alpha-\mathbf{N}$ & $\alpha-\mathbf{S}$ & $\alpha-\mathbf{C}$ & $\mathbf{M e t}(\mathbf{S} \cdot \mathbf{N})^{+}$ & $\mathbf{M e t}^{+} \cdot \mathbf{S} \cdot \mathbf{S}^{+}$ \\
\hline \multirow{2}{*}{$1.4 \mu \mathrm{s}$} & 0.34 & 0.14 & 0.052 & 0.035 & 0.029 \\
& $(57.1 \%)$ & $(23.6 \%)$ & $(8.6 \%)$ & $(5.9 \%)$ & $(4.8 \%)$ \\
$3.5 \mu \mathrm{s}$ & 0.35 & 0.13 & 0.061 & 0.029 & 0.027 \\
& $(58.7 \%)$ & $(21.8 \%)$ & $(10.2 \%)$ & $(4.8 \%)$ & $(4.5 \%)$ \\
\hline
\end{tabular}

(a) G-values are in $\mu \mathrm{mol} \mathrm{J}{ }^{-1}$ units; ${ }^{\text {(b) }}$ [Gly-Met-Gly] $=0.2 \mathrm{mM}$.

It is worthwhile to note that the contribution of MetS. $\mathrm{OH}$ is neglected for short times after the pulse, which means that its lifetime is very short. This observation can be rationalized by analogy with peptides containing C-terminal Met (see Section 3.1.1), in terms of a concerted process which involves a fast proton transfer from the $\mathrm{N}$-terminal $-\mathrm{NH}_{3}{ }^{+}$group to the MetS: $\mathrm{OH}$ moiety, which eliminates $\mathrm{HO}^{-}$(in the form of water) occurs and leads by sequential steps to $\alpha-\mathrm{N}$ radicals (Scheme 11). It has to be stressed at this point that $\alpha-\mathrm{N}$ and $\alpha$-S radicals are the most abundant radicals resulting from the ${ }^{\bullet} \mathrm{OH}$-induced oxidation of Gly-Met-Gly and constitute more than $80 \%$ of all of the radicals. Despite the fact that the carboxyl group in Gly residue is free, the pseudo Kolbe reaction does not operate in this case which was confirmed by the lack of $\mathrm{CO}_{2}$ [57]. Acetylation of the Nterminal amino group in Gly-Met-Gly eliminates any fast proton transfer to the MetS. $\mathrm{OH}$ moiety which is reflected in the longer lifetime of MetS. $:$ OH radicals, and as a consequence, their substantial contribution at short times after the electron pulse (Table 6). 
Table 6. The radiation chemical yield $(G){ }^{(a)}$ of radicals and radical cations and their percentage contribution (in parenthesis) to the total yield of radicals formed in the reaction of ${ }^{\bullet} \mathrm{OH}$ radicals with N-Ac -Gly-Met-Gly ${ }^{(b)}$ [74].

\begin{tabular}{|c|c|c|c|c|c|}
\hline Time & MetS : OH & $\alpha-S$ & $\alpha-C$ & $\operatorname{Met}(\mathrm{S} .: \mathrm{N})^{+}$ & $\operatorname{Met}(S \cdot: S)^{+}$ \\
\hline $1.4 \mu \mathrm{s}$ & $\begin{array}{c}0.18 \\
(30.6 \%)\end{array}$ & $\begin{array}{c}0.17 \\
(29.9 \%)\end{array}$ & $\begin{array}{c}0.05 \\
(8.1 \%)\end{array}$ & $\begin{array}{c}0.10 \\
(17.7 \%)\end{array}$ & $\begin{array}{c}0.08 \\
(13.6 \%)\end{array}$ \\
\hline $3.5 \mu \mathrm{s}$ & $\begin{array}{c}0.07 \\
(11.8 \%)\end{array}$ & $\begin{array}{c}0.29 \\
(49.0 \%)\end{array}$ & $\begin{array}{c}0.02 \\
(3.8 \%)\end{array}$ & $\begin{array}{c}0.11 \\
(19.2 \%)\end{array}$ & $\begin{array}{c}0.10 \\
(16.3 \%)\end{array}$ \\
\hline
\end{tabular}

(a) G-values are in $\mu \mathrm{mol} \mathrm{J^{-1 }}$ units; $^{\text {(b) }}$ [N-Ac-Gly- Met-Gly] $=0.2 \mathrm{mM}$.

Moreover, formation of the multi-membered $S:$ N-bonded radical cation (precursors of $\alpha-\mathrm{N}$ radicals) is not possible and the sequential reaction steps leading to $\alpha-\mathrm{N}$ radicals are switched off (Scheme 11). This is confirmed by the fact that $\alpha-\mathrm{N}$ radicals were not necessary for inclusion in the spectral resolutions.

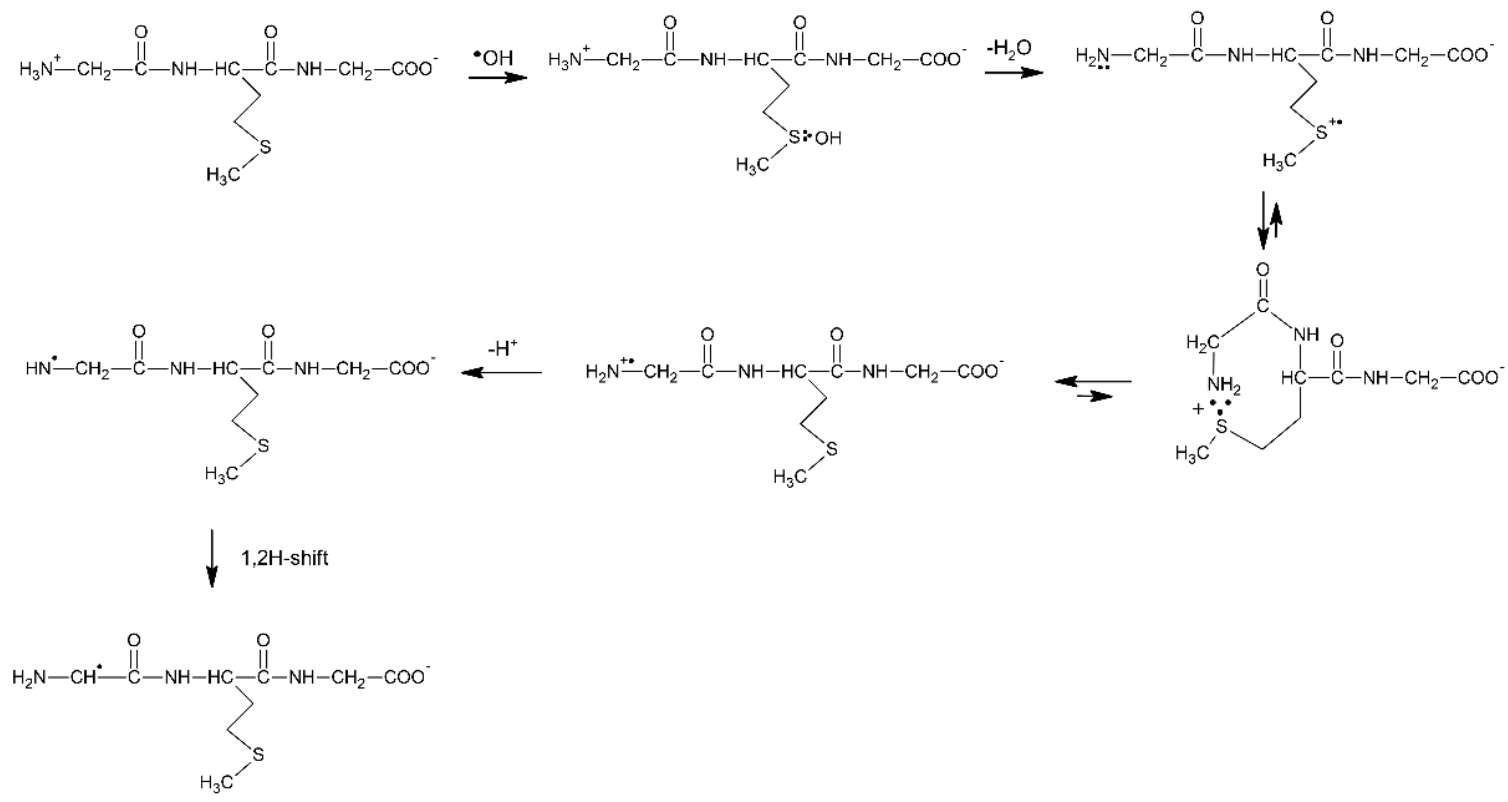

Scheme 11. General reaction scheme for ${ }^{\bullet} \mathrm{OH}$-induced oxidation of methionine in Gly-Met-Gly tripeptide.

The first experimental proof that Met can be oxidized by radicals with the reduction potentials lower than +1.4-1.6 V vs. NHE (which is equal to $\mathrm{E}^{0}\left(\mathrm{Met} \mathrm{S}^{\bullet+} / \mathrm{Met}\right)$ ) came from one-electron oxidation of $\beta$-amyloid peptide $\left(\beta\right.$-AP1-40) using $\mathrm{N}_{3} \bullet$ radicals with $\mathrm{E}^{0}\left(\mathrm{~N}_{3} \bullet / \mathrm{N}_{3}{ }^{-}\right)=1.33 \mathrm{~V}$ vs. NHE [92]. Thermodynamic considerations indicate that $\mathrm{N}_{3} \bullet$ should not oxidize Met residues unless the one-electron reduction potential of Met is lowered because of favorable environment. It was shown that Met $^{35}$ is the target in $\beta-A P 1-40$ oxidation. Molecular modeling studies showed that $\beta$-AP26-40 (a representative fragment of the native $\beta$-amyloid peptide ( $\beta$-AP1-42) has a large probability of forming $S-\mathrm{O}$ bonds between $\mathrm{Ile}^{31}$ and $\mathrm{Met}^{35}$ due to the specific structural properties of the polypeptide fragment (an $\alpha$-helical motif) (Figure 3) [93,94]. These results corroborate the reported role of $\mathrm{Met}^{35}$ in the toxicity and protein oxidation capacity of $\beta-\mathrm{AP}(1-40)$ [95-97]. 


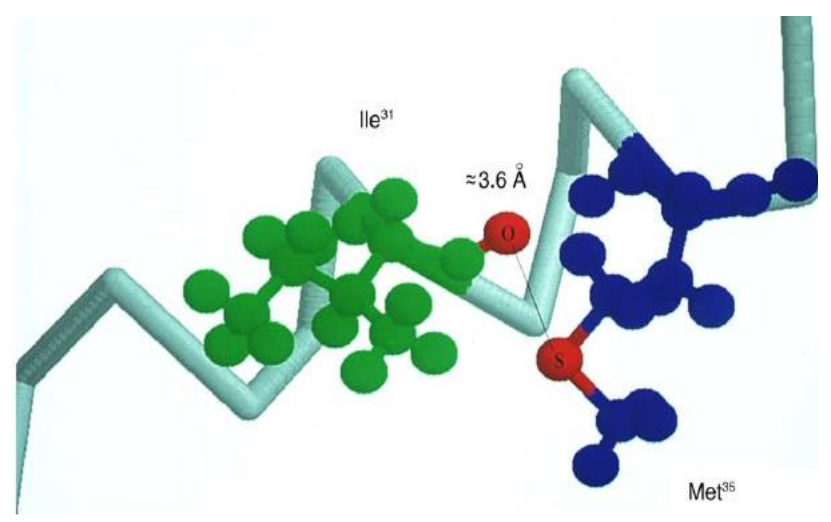

Figure 3. Schematic drawing of the $\alpha$-helical portion of the C-terminal region that encompasses Met $^{35}$ (reprinted with permission from [94]).

\subsubsection{Linear Peptides with Two Methionine Residues}

Contrary to cyclic dipeptides (see Section 4) extended conformers dominate in the linear (open chain) Met-Met dipeptides due to expressed tendency toward trans amides. Therefore, the close contacts between side chains of Met residues should be enhanced in $\mathrm{D}, \mathrm{L}-$ and, $\mathrm{L}, \mathrm{D}$-stereoisomers in comparison to $\mathrm{L}, \mathrm{L}-$ and $\mathrm{D}, \mathrm{D}$-stereoisomers (see Section 4.1.2). However, one should expect weaker steric constraints in linear peptides in comparison to cyclic dipeptides (see Section 4).

The reaction of ${ }^{\bullet} \mathrm{OH}$ radicals with four stereoisomers was investigated by pulse radiolysis with time-resolved UV-vis spectrophotometry in $\mathrm{Ar}$ or $\mathrm{N}_{2} \mathrm{O}$ saturated aqueous solutions at $\mathrm{pH} 1$ and $\mathrm{pH}$ 5.2, respectively [9]. The absorption bands observed at $\mathrm{pH} 1$ for D,L-, L,D-, $\mathrm{L}, \mathrm{L}-$, and D,D-stereoisomers were characterized by a maximum with $\lambda_{\max }=490 \mathrm{~nm}$ and similar molar absorption coefficients $\varepsilon_{490}=5900,5550,5500$, and $5800 \mathrm{M}^{-1} \mathrm{~cm}^{-1}$, and were unequivocally assigned to intramolecular $\operatorname{Met}(\mathrm{S} \cdot . \mathrm{S})^{+}$radical cations. The similarity between the maximum positions and the molar absorption coefficients suggests similar overlap of p-orbitals of sulfur atoms and thus a similarity in the strength of the S. S-bond in the radical cations derived from all of the optical isomers $[98,99]$ and thus confirming weaker steric constrains in linear peptides than in cyclic dipeptides (see Section 4.1.2), whereas the influence of the stereoisomerism was manifested in the decay rates of $\operatorname{Met}(\mathrm{S} \cdot \mathrm{S})^{+}$radical cations: first order decay rate constants were measured at $\mathrm{pH} 1: 6.2 \times 10^{3} \mathrm{~s}^{-1}$ (L,L-isomer), $8.3 \times 10^{3} \mathrm{~s}^{-1}$ (D,D-isomer), $3.9 \times 10^{3} \mathrm{~s}^{-1}$ (L,D-isomer), and $3.7 \times 10^{3} \mathrm{~s}^{-1}$ (D,L-isomer). These Met(S. $: S)^{+}$radical cations are in an equilibrium with the respective monomeric sulfur radical cations $\left(\mathrm{MetS}^{\bullet+}\right.$ ) The observed differences can be understood in terms of different equilibrium constants $\left(\mathrm{K}_{\mathrm{eq}}\right)$ due to different distances between the $\mathrm{NH}_{3}{ }^{+}$group and the positively charged S-atom. At $\mathrm{pH}=5$ the transient absorption observed for L-Met-L-Met was characterized by a strong absorption band with $\lambda_{\max }=390 \mathrm{~nm}$ which was assigned inter alia to $\operatorname{Met}\left(\mathrm{S} \cdot{ }^{\cdot} \mathrm{N}\right)^{+}$radical cation which are formed via dehydroxylation of the primary MetS. $\mathrm{OH}$ radical at the $\mathrm{N}$-terminal Met assisted by an intramolecular proton transfer from the $\mathrm{NH}_{3}{ }^{+}$group. A weaker absorption band with $\lambda_{\max }=290 \mathrm{~nm}$ was assigned to $\alpha-$ (alkylthio)alkyl radicals ( $\alpha-\mathrm{S})$. Because of neutral character of ${ }^{\bullet} \mathrm{OH}$ radicals it is reasonable to assume that both sulfur atoms located in the $\mathrm{N}$-terminal and $\mathrm{C}$-terminal Met residues are attacked by ${ }^{\bullet} \mathrm{OH}$ radicals with the same efficiency. Dehydroxylation of MetS. $\therefore \mathrm{OH}$ at the C-terminal Met can be also assisted by an intramolecular proton transfer from the $\mathrm{NH}_{3}{ }^{+}$in the process analogous to Gly-Met-Gly tripeptide (see Section 3.1.2, Scheme 11). In this case, the monomeric sulfur cations $\left(\mathrm{MetS}^{\bullet+}\right)$ can form an intramolecular $\operatorname{Met}(\mathrm{S}: \mathrm{O})^{+}$ radical cation, deprotonate to $\alpha$-S radicals, and undergo a pseudo Kolbe reaction that leads to decarboxylation. The last reaction can be excluded based on the photochemical experiments where L-Met-L-Met was oxidized by the triplet of 4-carboxybenzophenone (see Section 3.2.2) and no $\mathrm{CO}_{2}$ was detected. 
Similarly, as for the $\gamma$-Glu-(Pro) $)^{-M e t}(n=0-3)$ oligopeptides (see Section 3.1.1), the Met-(Pro) ${ }_{n}$-Met $(n=0-4)$ oligopeptides were chosen as oligopeptides with restricted conformational flexibility. The radiation chemical yields of intramolecular $\operatorname{Met}(S \cdot S)^{+}$radical cations depend on the number of Pro-residues; however, they do not depend in a simple way on the average distance between the sulfur atoms in the Met residues. The analysis showed that formation of a contact between terminal Met residues in the peptides with 0-2 Pro residues is controlled by the activated formation of $\operatorname{Met}(\mathrm{S} \cdot \mathrm{S} \cdot \mathrm{S})^{+}$whereas in the peptides with 3-4 Pro residues, by the relative diffusion of the $\mathrm{MetS}^{\bullet+}$ and the unoxidized sulfur atom. A decrease in the yields of $\operatorname{Met}(\mathrm{S} \cdot \mathrm{S} \cdot \mathrm{S})^{+}$species with an increase in the number of Pro residues occurs at the expense of an increase in the yields of intramolecular $\operatorname{Met}(\mathrm{S}: \mathrm{O})^{+}$ radical cations, and $\alpha$-(alkylthio)alkyl radicals $(\alpha-S)$ [100]. These findings were similar to those obtained for the photo-induced oxidation of Met-(Pro $)_{n}$-L-Met peptides by the triplet state of CB (see Section 3.2.2, Scheme 12).

\subsection{Photo-Induced Oxidation}

\subsubsection{Methionine as the N/C-Terminal and the Internal Amino Acid Residue}

The quenching of $\mathrm{CB}$ triplets by methionine-containing peptides occurs with rate constants of the order of $2-3 \times 10^{9} \mathrm{M}^{-1} \mathrm{~s}^{-1}$ (Table 2). Small differences in the quenching rate constants (indicating the existence of multiple sulfur targets in the quenching process) were interpreted and discussed in reference [16]. The formation of the electron transfer products such as $\mathrm{CB}^{--}$radical anion, $\mathrm{CBH}^{\cdot}$ ketyl radical and $(\mathrm{S} \cdot: \mathrm{N})^{+}$and $(\mathrm{S} \cdot: \mathrm{S})^{+}$transients observed in the nanosecond laser flash photolysis indicated that the quenching is electron transfer in nature. As in the case of methionine derivatives, the mechanism of the primary steps in the photooxidation can be described by three primary reactions of the CT complex $\left[\mathrm{CB}^{--} \ldots>\mathrm{S}^{++}\right.$]: (i) charge separation $\left(\mathrm{k}_{\mathrm{sep}}\right)$ yielding $\mathrm{CB}^{--}$and $>\mathrm{S}^{++}$radical ions, (ii) proton transfer within the CT complex $\left(\mathrm{k}_{\mathrm{H}}\right)$ yielding a ketyl radical CBH' and an $\alpha$-(alkylthio)alkyl radical $(\alpha \mathrm{S})$, and (iii) back electron transfer $\left(\mathrm{k}_{\mathrm{bt}}\right)$ (Scheme 8$)$. In the case of peptides with an $\mathrm{N}$-terminal methionine residue at low $\mathrm{pH}$, an additional, fourth primary reaction (namely proton transfer from the protonated amino group $\left(-\mathrm{NH}_{3}{ }^{+}\right)$to the $\mathrm{CB}{ }^{--}$radical anion within the CT complex ( $\mathrm{k}_{\mathrm{NH}}$ reaction-see Scheme 8 ) was present. The quantum yields of primary intermediates in the CB-sensitized photooxidation of Met peptides are summarized in Table 7.

An analysis of these results led to conclusions similar to those for methionine derivatives. For peptides with the N-terminal methionine residue (Met-Gly, Met-Gly-Gly, Met-Lys, Met-Met) at low $\mathrm{pH}$, the $\mathrm{k}_{\mathrm{NH}}$ reaction was responsible for the large values of the quantum yields of $\mathrm{CBH}^{\bullet}$ and the $(\mathrm{S}: \mathrm{N})^{+}$intermediate. At high $\mathrm{pH}$, the charge separation reaction $\left(\mathrm{k}_{\text {sep }}\right)$ was the main primary reaction of the $\mathrm{CT}$ complex $\left[\mathrm{CB}^{\bullet-} \ldots>\mathrm{S}^{\bullet+}\right]$ and large values of $\Phi_{\mathrm{CB} \bullet-}$ and $\Phi_{(\mathrm{S}: \mathrm{N})+}$ were observed. Secondary reactions of the $(\mathrm{S}: \mathrm{N})^{+}$radical cation in alkaline solutions for Met-Gly peptide ( $\mathrm{pH}$ 9-11) studied by laser flash photolysis were described in detail in reference [17]. In the case of peptides with C-terminal methionine regardless of $\mathrm{pH}$, the intermolecular dimeric sulfur radical cations $\left(\mathrm{S} \cdot \mathrm{S} \cdot \mathrm{S}^{+}\right.$were the main intermediates. The decarboxylation reaction was not observed (or could be neglected in comparison to the other efficient reactions) for Met-containing peptides. This indicates that for peptides with a $C$-terminal methionine the main irreversible reaction of the sulfurcentered radical cation $>S^{\bullet+}$ was deprotonation leading to the $\alpha$-(alkylthio)alkyl radical $(\alpha S)$ but a competing decarboxylation reaction could be neglected. This interpretation was additionally confirmed in the steady-state irradiation experiments, where radical coupling stable products $\mathrm{CBH}-\alpha \mathrm{S}$ were detected [20]. 
Table 7. Quantum yields of primary intermediates and $\mathrm{CO}_{2}$ in the $\mathrm{CB}$-sensitized photooxidation of Met-containing linear peptides.

\begin{tabular}{|c|c|c|c|c|c|c|c|c|}
\hline $\begin{array}{l}\text { Met-Containing } \\
\text { Peptides }\end{array}$ & $\mathrm{pH}$ & $\Phi_{\mathrm{CBH}} \cdot(\mathbf{b})$ & $\boldsymbol{\Phi}_{\mathrm{CB}} \cdot-(\mathrm{b})$ & $\begin{array}{c}\Phi_{\mathrm{CBH}}+ \\
\Phi_{\mathrm{CB}} \cdot-(b)\end{array}$ & $\Phi_{(\mathrm{S}: \mathrm{N})}{ }^{+(\mathrm{b})}$ & $\Phi_{(\mathrm{S} \cdot: \mathrm{S})}{ }^{+(\mathrm{b})}$ & $\Phi_{\mathrm{CO} 2}-{ }^{(c)}$ & Lit \\
\hline Met-Gly & 6 & 0.25 & 0.13 & 0.38 & 0.18 & $\sim 0.04$ & 0.01 & {$[16,18]$} \\
\hline Met-Gly & 11 & 0.06 & 0.55 & 0.61 & 0.51 & $\sim 0.04$ & 0.01 & {$[16,18,75]$} \\
\hline Gly-Met & 6 & 0.15 & 0.22 & 0.37 & 0 & 0.22 & 0.02 & [18] \\
\hline Gly-Met & 11 & 0.10 & 0.32 & 0.42 & 0 & 0.24 & 0.02 & [18] \\
\hline Met-Gly-Gly & 6 & $\sim 0.29$ & $\sim 0.06$ & $\sim 0.35$ & 0.14 & $\sim 0.08$ & 0.01 & {$[16]$} \\
\hline Met-Gly-Gly & 11 & 0.09 & 0.49 & 0.58 & 0.30 & $<0.03$ & - & [16] \\
\hline Gly-Gly-Met & 6 & 0.19 & 0.25 & 0.44 & 0 & 0.24 & 0.02 & [16] \\
\hline Gly-Gly-Met & 11 & 0.13 & 0.30 & 0.43 & 0 & 0.29 & - & {$[16]$} \\
\hline Gly-Met-Gly & 6 & 0.24 & 0.05 & 0.29 & 0 & 0.08 & 0.02 & [16] \\
\hline Gly-Met-Gly & 11 & 0.10 & 0.21 & 0.31 & 0 & 0.07 & - & [16] \\
\hline Met-Lys & 6 & 0.55 & $\sim 0.03$ & 0.58 & 0.33 & 0 & 0 & [20] \\
\hline Lys-Met & 6 & 0.63 & 0 & 0.63 & 0 & 0.19 & 0 & [20] \\
\hline Met-Enkephalin & 7 & - & - & 0.82 & 0 & 0 & 0 & [61] \\
\hline
\end{tabular}

(a) $[C B]=2-4 \mathrm{mM}$, [Met peptides $]=5-20 \mathrm{mM}$; ${ }^{\text {(b) }}$ error $\pm 20 \%$; ${ }^{\text {(c) }}$ error $\pm 50 \%$.

In the case of methionine as the internal amino acid residue (Gly-Met-Gly), the results from the CB-sensitized photooxidation were discussed based on the general mechanism presented in Scheme 8. Four primary reactions of CT complex $\left[\mathrm{CB}^{--} \ldots>\mathrm{S}^{++}\right]$could occur:

(i) charge separation $\left(\mathrm{k}_{\mathrm{sep}}\right)$ yielding $\mathrm{CB}^{--}$and $>\mathrm{S}^{++}$radical ions, (ii) proton transfer within the CT complex $\left(\mathrm{k}_{\mathrm{H}}\right)$ yielding a ketyl radical $\mathrm{CBH}^{-}$and an $\alpha$-(alkylthio)alkyl radical $(\alpha S)$, (iii) back electron transfer $\left(\mathrm{k}_{\mathrm{bt}}\right)$, and (iv) proton transfer from the protonated amino group $\left(-\mathrm{NH}_{3}{ }^{+}\right)$of Gly to the $\mathrm{CB}^{--}$radical anion within the CT complex $\left(\mathrm{k}_{\mathrm{NH}}\right)$. At low $\mathrm{pH}$ the $\mathrm{k}_{\mathrm{NH}}$ and $\mathrm{k}_{\mathrm{H}}$ reactions were the main reaction channels $\left(\Phi_{\mathrm{CBH}} \cdot=0.24\right)$ in comparison with the less efficient reaction of charge separation $\left(\Phi_{\mathrm{CB} \bullet-}=0.05\right)$ (Table 5). It is noteworthy that in this case, the $\mathrm{k}_{\mathrm{NH}}$ reaction does not lead to the $(\mathrm{S} \cdot \mathrm{N})^{+}$transient as for an N-terminal methionine residue in peptides. (For expected products from a decay of $>S^{\cdot+}$ radical ions containing unprotonated amino group in the Gly residue see Scheme 11). In basic solutions, the charge separation reaction $\left(\mathrm{k}_{\mathrm{sep}}\right)$ was the main reaction channel yielding $\mathrm{CB}^{-}$and $>\mathrm{S}^{+}$ radical ions $\left(\Phi_{\mathrm{CB} \bullet-}=0.21\right) .(\mathrm{S} \cdot \mathrm{N})^{+}$cyclic radical cations involving a nitrogen atom from a peptide bond was not observed.

The mechanism of CB-sensitized oxidation of Met-Gly and Gly-Met peptides was also studied by the time-resolved CIDNP technique by Morozova et al. [24] at various $\mathrm{pH}$ values. It was shown that at low $\mathrm{pH}$ for both peptides a sulfur-centered radical cation $>\mathrm{S}^{\bullet+}$ was formed. For Met-Gly, the $>S^{\bullet+}$ radical cation was converted (after deprotonation) to the $(\mathrm{S} \cdot \mathrm{N})+$ radical cation with five-membered cyclic structure. In basic solutions the main transients for Met-Gly were $(\mathrm{S}: \mathrm{N})^{+}$radical cations and aminyl type radicals; however, for Gly-Met, the $>S^{\bullet+}$ radical cations and aminyl type radicals were the main transients.

The mechanism proposed on the basis of the CIDNP experiments correlates with that obtained on the basis of laser flash photolysis experiments with an exception of aminyl radicals. (These radicals were not identified in the laser flash photolysis experiments, see Section 2.2.1).

\subsubsection{Linear Peptides with Two Methionine Residues}

In the case of Met-Met peptides (Table 8), as was presented in reference [63], the CBsensitized photooxidation led to formation of intramolecular two-centered three-electron bonded $(S \cdot S)^{+}$radical cations that can compete with the formation of intramolecular 
$(\mathrm{S}: \mathrm{N})^{+}$radical cations at low $\mathrm{pH}$ via the $k_{\mathrm{NH}}$ reaction (see Scheme 6) and at high $\mathrm{pH}$ via cyclization of $>\mathrm{S}^{\bullet+}$ radical cations.

Table 8. Quantum yields of primary intermediates and $\mathrm{CO}_{2}$ in the $\mathrm{CB}$-sensitized photooxidation of peptides containing two methionine residues.

\begin{tabular}{|c|c|c|c|c|c|c|c|c|}
\hline $\begin{array}{c}\text { Met-Containing } \\
\text { Peptides (a) }\end{array}$ & $\mathrm{pH}$ & $\Phi_{\mathrm{CBH}} \cdot(b)$ & $\Phi_{\mathrm{CB}} \cdot-(\mathbf{b})$ & $\begin{array}{l}\Phi_{\mathrm{CBH}}+ \\
\Phi_{\mathrm{CB}} \cdot- \\
\end{array}$ & $\Phi_{(S: N)}{ }^{+(b)}$ & $\Phi_{(S \cdot S)}{ }^{+(b)}$ & $\Phi_{\mathrm{CO}^{-2}}{ }^{(\mathrm{c})}$ & Lit \\
\hline L-Met-L-Met & 6 & 0.23 & 0.15 & 0.38 & 0.19 & $0.07^{(\mathrm{d})}$ & $<0.01$ & {$[63]$} \\
\hline L-Met-L-Met & 10 & 0.13 & 0.41 & 0.54 & 0.43 & $0.01^{(\mathrm{d})}$ & $<0.01$ & {$[63]$} \\
\hline D-Met-D-Met & 6 & 0.24 & 0.18 & 0.42 & 0.27 & $0.069^{(\mathrm{d})}$ & - & {$[63]$} \\
\hline D-Met-D-Met & 10 & 0.09 & 0.40 & 0.49 & 0.41 & $(\sim 0.02 \mathrm{~d})$ & - & {$[63]$} \\
\hline L-Met-D-Met & 6 & 0.17 & 0.23 & 0.40 & 0.18 & $0.15^{(\mathrm{d})}$ & $<0.01$ & {$[63]$} \\
\hline L-Met-D-Met & 10 & 0.08 & 0.37 & 0.45 & 0.34 & $0.06^{(\mathrm{d})}$ & $<0.01$ & {$[63]$} \\
\hline D-Met-L-Met & 6 & 0.15 & 0.25 & 0.40 & 0.15 & $0.16^{(\mathrm{d})}$ & $<0.01$ & {$[63]$} \\
\hline D-Met-L-Met & 10 & 0.10 & 0.38 & 0.48 & 0.36 & $0.06^{(\mathrm{d})}$ & $<0.01$ & {$[63]$} \\
\hline c-(L-Met-L-Met) & 7 & 0.17 & 0.19 & 0.36 & 0 & $0.14^{(\mathrm{d})}$ & - & {$[63]$} \\
\hline
\end{tabular}

(a) $[C B]=2 \mathrm{mM}$, [Met-peptides] $=0.5 \mathrm{mM}^{\text {(b) }}$ errors $\pm 10-20 \%{ }^{\text {(c) }}$ error $\pm 50 \%$; ${ }^{(\mathrm{d})}$ intramolecular $(\mathrm{S} \cdot \mathrm{S})^{+}$(adapted $^{\text {(a) }}$ after [3])

At high $\mathrm{pH}$, the charge separation reaction $\left(k_{\mathrm{sep}}\right)$ yielding $\mathrm{CB}^{--}$and $>\mathrm{S}^{+}$radical ions was shown to be the main primary process involved in the decay of the $\left[\mathrm{CB}^{--} \ldots>\mathrm{S}^{++}\right]$ complex and the quantum yield of $\mathrm{CB}^{--}$was equal to the sum of quantum yields of the sulfur radical cations $(\mathrm{S} \cdot \mathrm{N})^{+}$and $(\mathrm{S} \cdot \mathrm{S} \cdot)^{+}$. At low $\mathrm{pH}$, in addition to the charge separation reaction $\left(k_{\text {sep }}\right)$ reaction the proton transfer rection from the protonated amino group $\left(-\mathrm{NH}_{3}{ }^{+}\right)$ to the $\mathrm{CB}^{-}$radical anion within the $\mathrm{CT}$ complex $\left(k_{\mathrm{NH}}\right.$ reaction-see Scheme 8) was present. Small differences in the values of quantum yields for $(S \cdot S)^{+}$and $(S \cdot: N)^{+}$radical cations were found for mixed L,D or D,L stereoisomers of Met-Met and L,L or D-D stereoisomers. However, for mixed stereoisomers the quantum yields of $(\mathrm{S}: \mathrm{N})^{+}$radical cations went down at the expense of higher values for $(S \cdot S)^{+}$radical cations in both acidic and basic solutions. In addition, for mixed stereoisomers the quantum yields of $(\mathrm{S} \cdot \mathrm{S} \cdot \mathrm{S})^{+}$radical cations were more than twice higher of those for $\mathrm{L}, \mathrm{L}$ and $\mathrm{D}, \mathrm{D}$ stereoisomers. These observations were rationalized by the higher propensity of $\left((\mathrm{S} \cdot \mathrm{S})^{+}\right.$formation for mixed stereoisomers.

As was mentioned previously (see Section 3.1.3), the L-Met-(Pro)n-L-Met peptides with Met residues located on $\mathrm{N}$ - and $\mathrm{C}$ - termini were shown to be excellent models of oligopeptides for studying the intramolecular interaction between two sulfur atoms in oligopeptides since this series of Met-(Pro $)_{n}$-Met peptides provides the investigator with the possibility for controlling the S... S distance (Scheme 12).

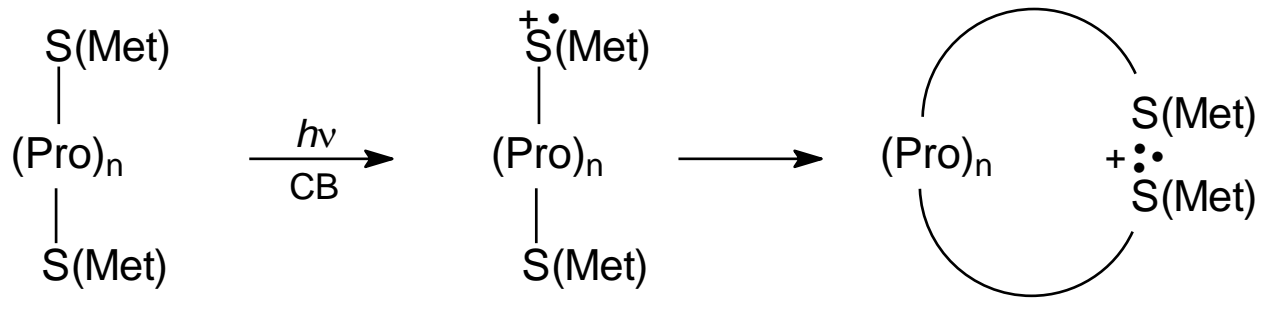

Scheme 12. Formation of intramolecular dimeric sulfur radical cations $(S \cdot S)^{+}$in photo-induced oxidation of Met-(Pro $)_{n}$-Met oligopeptides.

This is important because amino acid chains can serve as relay stations for electron transfer processes. As shown in Scheme 8, in the CB-sensitized photooxidation of methionine containing compounds (photochemical path), the sulfur-centered monomeric radical cations $\left(>S^{+}\right)$were formed. The $>S^{++}$radical cations (regardless of location on $\mathrm{N}$ or $C$ termini) can be stabilized by formation of the intramolecular dimeric sulfur radical cations $(\mathrm{S} \cdot \mathrm{S})^{+}$, and $(\mathrm{S}: \mathrm{O})^{+}$or $(\mathrm{S} \cdot \mathrm{N})^{+}$intermediates or decay by deprotonation leading to 
$\alpha$-(alkylthio)alkyl radicals $(\alpha \mathrm{S})$. The nanosecond laser flash photolysis experiments and the resolution of transient absorption spectra allowed the investigators to monitor kinetics and quantum yields of the intermediates at various time delays after the excitation laser pulse [68]. It was found that a decrease in the quantum yield $(\Phi)$ of the $(S \cdot: S)^{+}$intermediate with the number of proline residues occurred at the expense of quantum yields $(\Phi)$ of the other intermediates: $(\mathrm{S} .: \mathrm{O})^{+} /(\mathrm{S} \cdot: \mathrm{N})^{+}$and $\alpha \mathrm{S}$ radicals. However, the dependence of $\Phi(\mathrm{S} \cdot: \mathrm{S})^{+}$ on the average distance between sulfur atoms was not linear (the largest change in $\Phi\left(S \cdot{ }^{\prime} S\right)^{+}$ was observed when the number of proline residues was changed from two to three). These observations were reproduced by Langevin dynamics and statistical mechanical theory showing that for peptides with zero to two Pro residues contact between sulfur atoms was controlled by the activated formation of $(\mathrm{S}: \mathrm{S})^{+}$but for the peptides with three and four proline residues was controlled by relative diffusion of the $>\mathrm{S}^{++}$radical cation and an unoxidized S atom [68]. These findings were similar to those obtained for the radiation-induced oxidation of Met-(Pro) $)_{n}$-L-Met peptides by ${ }^{\bullet} \mathrm{OH}$ radicals (see Section 3.1.3).

\section{Methionine in Cyclic Peptides}

Non-extended conformers dominate in the cyclic structures of Met-Met dipeptides due to the expressed tendency toward cis amides. Therefore, the side chains of Met residues in L, L-configured cyclic dipeptides are on the same side of a diketopiperazine ring and, as a consequence, close contacts between them are enhanced (Figure 4a). On the other hand, the side chains of Met residues in L,D-configured cyclic dipeptides are on opposite sides of a diketopiperazine ring and their close contacts are difficult if not impossible, due to the strong steric constraints in the diketopiperazine ring (Figure $4 \mathrm{~b}$ ). Moreover, the presence of free terminal amino and carboxyl groups is eliminated and, thus, stabilization of monomeric sulfur radical cations $\left(\mathrm{MetS}^{\bullet+}\right.$ ) can come solely from interactions with lone electron pairs on the sulfur atoms in the side chains and/or with lone pairs on the heteroatoms ( $\mathrm{N}$ - and O-atoms) associated with the peptide bonds.

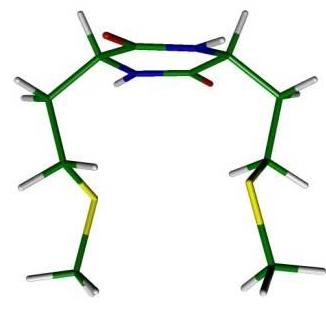

(a)

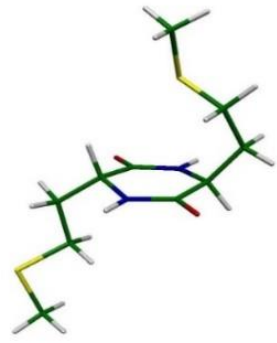

(b)

Figure 4. Schematic drawing of structures of (a) the cyclic L-Met-L-Met dipeptide and (b) the cyclic L-Met-D-Met dipeptide.

\subsection{Radiation-Induced Oxidation}

\subsubsection{Cyclic Dipeptides with Single Met Residue}

Oxidation of c-(Gly-L-Met) dipeptide by ${ }^{\bullet} \mathrm{OH}$ radicals was mainly aimed at determining whether in the case of c-(D-Met-L-Met) intramolecular Met $(\mathrm{S} \cdot \mathrm{S})^{+}$radical cations or intermolecular dimeric radical cations (MetS. SMet) ${ }^{+}$are formed (see Section 4.1.2) [13]. The oxidation pattern observed in c-(Gly-L-Met) dipeptide in which there is no chance of forming an intramolecular Met(S. $: S)^{+}$radical cation is exactly the same as observed in c-(D-Met-L-Met). Similarities in the spectral and kinetic features observed in c-(Gly-L-Met) and c-(D-Met-L-Met) clearly indicate that the mechanisms of OH-induced oxidation of both peptides and the nature of the intermediates are the same for both dipeptides (see Section 4.1.2, Scheme 14). 


\subsubsection{Cyclic Dipeptides with Two Met Residues}

For the above conformational reasons, cyclic Met-Met dipeptides are suitable models compounds to study reaction of MetS. $\mathrm{OH}$ and $\mathrm{MetS}^{\bullet+}$ in oligopeptides and proteins containing multiple and adjacent Met residues (e.g., calmodulin $\mathrm{CaM}^{-\mathrm{Ca}_{4}}$ (see Section 5.1), human prion proteins hPrP [101], $\alpha$-synuclein [102]). A small model cyclic dipeptide c-(L-Met-L-Met) (see Figure 3a) was oxidized by ${ }^{\bullet} \mathrm{OH}$ radicals generated by pulse radiolysis and the ensuing reactive intermediates were monitored by time-resolved UV-vis spectroscopy and conductometry [12]. Nearly similar radiation chemical yields of intramolecular $\operatorname{Met}(S \cdot: N)$ radicals and intramolecular $\operatorname{Met}\left(S \cdot{ }^{\prime} S\right)^{+}$radical cations are formed (see Table 9) in the competitive processes from the primary formed MetS. OH adduct (Scheme 13).

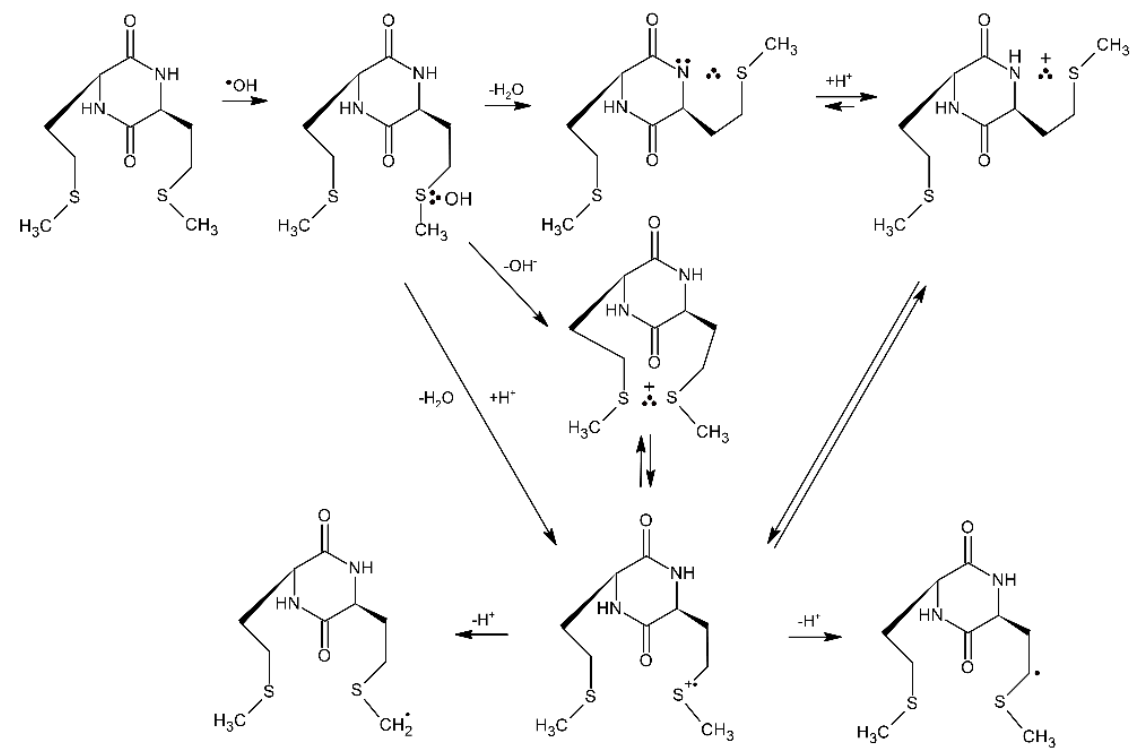

Scheme 13. General reaction scheme for ${ }^{\bullet} \mathrm{OH}$-induced oxidation of methionine in c-(L-Met-L-Met).

One feature that requires a note is that the neutral Met $(S \cdot: N)$ radical seems to arise directly from an intermediary MetS. OH adduct rather than going through the monomeric $\mathrm{MetS}^{\bullet+}$ radical cation. Mechanistically, this involves a concerted deprotonation and $\mathrm{HO}^{-}$ elimination from MetS: $\mathrm{OH}$. which frees up an electron pair on the $\mathrm{N}$-atom of the peptide bond. Ultimately, the $\operatorname{Met}(\mathrm{S}: \mathrm{N})$ radicals decayed via two-different $\mathrm{pH}$-dependent reaction pathways: (i) at low $\mathrm{pH}$ by conversion into additional $\mathrm{Met}(\mathrm{S} \cdot \mathrm{S})^{+}$radical cations via the

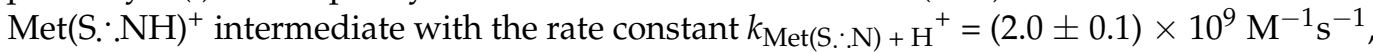
and (ii) at $\mathrm{pH}$ close to neutral by a series of consecutive reactions involving, protonation, hydrolysis, and electron transfer followed by decarboxylation of the N-centered radical on Met (not shown in Scheme 13) [12]. The observed decrease of formation of $\operatorname{Met}(S \cdot S)^{+}$radical cations via pathway (i) with $\mathrm{pH}$ is clearly corroborated by the respective $G\left(\operatorname{Met}\left(\mathrm{S} \cdot\right.\right.$.S $^{+}$ values recorded at various $\mathrm{pH}$ values before and after decay of $\operatorname{Met}(\mathrm{S}: \mathrm{N})$ (Table 9). Interestingly, an absorption band assigned to $\operatorname{Met}(\mathrm{S} \cdot \mathrm{S})^{+}$in c-(L-Met-L-Met) is characterized by $\lambda_{\max }=520 \mathrm{~nm}$ which is red shifted in comparison to $\lambda_{\max }=480 \mathrm{~nm}$ of the absorption band of intermolecular dimeric radical cations (MetS. :SMet) ${ }^{+}$in Met [7] or $\lambda_{\max }=490 \mathrm{~nm}$ of the absorption band of intramolecular $\operatorname{Met}(\mathrm{S} \cdot \mathrm{S})^{+}$radical cations in linear L-Met-L-Met dipeptides [9]. This phenomenon can be rationalized by the less favorable overlap of the p orbitals of sulfur atoms in c-(L-Met-L-Met) due to stronger steric constraints of diketopiperazine ring [98,99]. 
Table 9. Radiation chemical yields of intramolecular $\operatorname{Met}(\mathrm{S} \cdot \mathrm{N})$ and $\operatorname{Met}(\mathrm{S} \cdot \mathrm{S})^{+}$formed during - $\mathrm{OH}$-induced oxidation of the cyclic L-Met-L-Met dipeptide in $\mathrm{N}_{2} \mathrm{O}$-saturated aqueous solutions.

\begin{tabular}{|c|c|c|c|c|}
\hline Type of the Radical & $\mathrm{pH} 4$ & pH 4.3 & pH 4.9 & pH 5.3 \\
\hline Intramolecular & $0.26^{(\mathrm{a})}$ & $0.28^{(a)}$ & $0.25^{(a)}$ & $0.27^{(\mathrm{a})}$ \\
\hline $\operatorname{Met}(S \cdot: N)$ & 0 & 0 & 0 & 0 \\
\hline Intramolecular & $0.22^{(a)}$ & $0.23^{(a)}$ & $0.22^{(a)}$ & $0.23^{(a)}$ \\
\hline $\operatorname{Met}(S \cdot . S)^{+}$ & $0.45^{(\mathrm{a})}$ & $0.45^{(a)}$ & $0.32^{(a)}$ & $0.34^{(a)}$ \\
\hline
\end{tabular}

(a) in $\mu \mathrm{M} \mathrm{J}^{-1}$; [L-Met-L-Met] $=0.2 \mathrm{mM}$.

Oxidation of the cyclic dipeptide c-(D-Met-L-Met) by ${ }^{\bullet} \mathrm{OH}$ radicals induced by pulse radiolysis was also studied with combined time-resolved UV-vis spectroscopy and conductometry. This isomer has geometric restrictions which should impose limitations on stabilization of intramolecular $\operatorname{Met}(S \cdot S)^{+}$radical cations (see Figure $3 b$ ). In contrast to the previously observed intramolecular stabilization of $\mathrm{MetS}^{\bullet+}$ by the unoxidized sulfur atom in the neighboring Met, in the isomer c-(L-Met-L-Met) (Scheme 13 and Table 9), no similar intramolecular stabilization of $\mathrm{MetS}^{\bullet+}$ was observed in c-(D-Met-L-Met). One feature that requires a note at this point is that the species absorbing in the $480-490 \mathrm{~nm}$ range has to be assigned to intermolecular dimeric radical cations (MetS. SMet) ${ }^{+}$based on the spectral and kinetic features observed in c-(Gly-L-Met) (see Section 4.1.1).

However, formation of $\operatorname{Met}(\mathrm{S}: \mathrm{N})$ occurs via an analogous concerted deprotonation and $\mathrm{HO}^{-}$elimination mechanism from MetS. $\mathrm{OH}$ as in c-(L-Met-L-Met) (Scheme 14).<smiles>CSCC[C@@H]1NC(=O)[C@@H](CCSC)NC1=O</smiles><smiles>CSCCC1NC(=O)[C@H](CCSC)NC1=O</smiles>

Scheme 14. General reaction scheme for ${ }^{\bullet} \mathrm{OH}$-induced oxidation of methionine in c-(D-Met-L-Met).

\subsection{Photo-Induced Oxidation}

\subsubsection{Cyclic Dipeptides with Single Met Residue}

One of the simplest model compounds for sensitized photooxidation are diketopiperazinebased benzophenone-methionine dyads: c-(L-BP-L-Met) and c-(L-BP-D-Met) with their structures presented in Figure 5 [76]. They allowed the investigators to study the intramolecular quenching of BP triplets by Met in conformationally controlled donor-acceptor pairs and to study the dynamics of the intermediates formed in the oxidation process. 
<smiles>CSCCC1NC(=O)C(Cc2ccc(C(=O)c3ccccc3)cc2)NC1=O</smiles><smiles>CSCCC1NC(=O)C(Cc2ccc(C(=O)c3ccccc3)cc2)NC1=O</smiles>

Figure 5. Structures of diketopiperazine-based benzophenone-methionine dyads: c-(L-BP-L-Met) (top) and c-(L-BP-D-Met) (bottom).

The combined results from time-resolved and steady-state experiments showed that for c-(L-BP-L-Met), the quenching occurred via electron transfer from the sulfur atom to the benzophenone triplet (via the $\left[\mathrm{BP}^{--} \ldots>\mathrm{S}^{-+}\right.$] complex) was followed by the proton transfer reaction that led to a biradical intermediate with the quantum yield $\Phi_{\text {ketyl }}=0.6$. These biradicals recombined to form a cyclic stable product via C-C coupling reaction. For the c(L-BP-D-Met) dyad, with its two reactive moieties on the opposite side of diketopiperazine ring, the quenching process and formation of biradical were shown to be less effective $\left(\Phi_{\text {ketyl }}<0.18\right)$. It was shown that differences in the reaction rates for both isomeric BP-Met dyads were attributed to the differences between the distribution of the carbonyl/sulfur atom distances in the two stereoisomers.

\subsubsection{Cyclic Dipeptides with Two Met Residue}

Cyclic Met-Met dipeptides are also suitable model compounds for proteins to study the photo-induced oxidation. They have the unique features of having no terminal groups and therefore they are good model to study interactions between a side chain and peptide bonds.

The mechanism of the CB-sensitized photooxidation of c-(L-Met-L-Met) with Met residues in the cis position was studied using nanosecond flash photolysis techniques [63]. The photochemical path of c-(L-Met-L-Met) oxidation led to the $>S^{+}$radical cation (as presented in Scheme 8). This radical cation can decay in two competing reactions: the formation of intramolecular dimeric sulfur radical cations $(S \cdot S)^{+}$and a deprotonation yielding $\alpha \mathrm{S}$ radicals. Similar to the results presented above for the radiation-induced oxidation, the efficiency of intramolecular $(S \cdot S)^{+}$formation was relatively large $(\Phi(S \cdot S)+=0.14$ (see Table 8 ) showing that this reaction was a main path of $>S^{++}$radical cation decay. The mechanism of $(\mathrm{S} . \mathrm{S}){ }^{+}$formation was shown to be similar to that presented in Scheme 13 for the radiation-induced oxidation of c-(L-Met-L-Met).

The CB-sensitized photooxidation of cyclic dipeptides containing methionine residues was also studied using time-resolved CIDNP [25]. For c-(D-Met-L-Met) with Met residues on the opposite side of the ring and for c-(Gly-Met) the sulfur-centered radical cations $>\mathrm{S}^{++}$ were detected. In the case of c-(L-Met-L-Met the intramolecular cyclic (S. SS) ${ }^{+}$transients with three-electron bond between two sulfur atoms were detected.

\section{Methionine in Proteins}

\subsection{Radiation-Induced Oxidation}

Pulse radiolysis is a very useful method for studies of free radical processes in biological systems, including proteins. However, the vast majority of studies was focused on the generation of unstable intermediates in proteins through one-electron reduction [103]. There were also some attempts aimed at studying the oxidation processes in proteins. However, they only concerned the oxidation of amino acids located in proteins which are very prone to oxidation, such as Trp or Tyr [5,104-107]. To the best of our knowledge, only 
two papers addressed radiation-induced oxidation of Met in proteins and the subsequent steps following oxidation [108,109].

Thioredoxin Ch1 (Trx) from Chlamydomonas reinhardtii contains two Met residues: $\mathrm{Met}^{41}$ and $\mathrm{Met}^{79}$. The one-electron oxidation of the W35A mutant of Trx by pulse radiolytically generated $\mathrm{N}_{3}{ }^{\bullet}$ radicals led to a transient absorption spectrum with three absorption bands characterized by $\lambda_{\max }=390,420$, and $480 \mathrm{~nm}$. The absorption band with $\lambda_{\max }=420 \mathrm{~nm}$ indicated formation of $\mathrm{TyrO}^{\bullet}$ radicals via direct reaction of Tyr with $\mathrm{N}_{3} \bullet$ radicals. On the other hand, the absorption bands with $\lambda_{\max }=390$ and $480 \mathrm{~nm}$ were assigned to $\operatorname{Met}(\mathrm{S} .: \mathrm{O})^{+}$ which results from the interaction of the monomeric sulfur radical cation $\left(\mathrm{MetS}^{\bullet+}\right)$ with the O-atom of the carbonyl function of $\mathrm{Phe}^{31}$ (which is less than $4 \AA$ away from S-atom) and $\operatorname{Met}(\mathrm{S}: \mathrm{S})^{+}$which results from the interaction of MetS ${ }^{\bullet+}$ with the S-atom of Cys ${ }^{49}$, respectively. With time evolution, no oxidized products derived from Met were detected but there was a further increase of the absorption band assigned to TyrO radicals. An intramolecular electron transfer from the Tyr residue to Met-derived radicals seems to be responsible for the latter observation [108] (see Scheme 15 for an analogous reaction involving $\operatorname{Met}(\mathrm{S} \cdot: \mathrm{N})^{+}$radical cation).

In turn, calmodulin $\left(\mathrm{CaM}-\mathrm{Ca}_{4}\right)$ (a regulatory "Ca-sensor protein") contains nine Met residues: $\mathrm{Met}^{36}, \mathrm{Met}^{51}, \mathrm{Met}^{71}, \mathrm{Met}^{72}, \mathrm{Met}^{76}, \mathrm{Met}^{109}, \mathrm{Met}^{124}$, Met ${ }^{144}$, and $\mathrm{Met}^{145}$ which are located in a variety of local environments. Therefore, the stabilization of the monomeric sulfur radical cation $\left(\mathrm{MetS}^{\bullet+}\right)$ can be realized in various ways depending upon local structures. The one-electron oxidation of $\mathrm{CaM}-\mathrm{Ca}_{4}$ using pulse radiolytically generated - $\mathrm{OH}$ radicals led to a transient absorption with $\lambda_{\max }=390 \mathrm{~nm}$ which shows a close similarity to that characteristic for $\mathrm{S}$ : $\mathrm{N}$-bonded radical cations observed in cyclic Met-Met dipeptides $[12,13]$. The lack of the characteristic spectrum of intramolecular S. S-bonded radical cation, despite the proximity of methionine residues in two pairs $\mathrm{Met}^{71} / \mathrm{Met}^{72}$ and $\mathrm{Met}^{144} / \mathrm{Met}^{145}$ can be rationalized by local steric constraints which prevent close contact of their side chains [13]. With time evolution, the transient absorption is shifted to $\lambda_{\max }=410 \mathrm{~nm}$ which is characteristic for TyrO $\mathrm{Cadicals}$. This observation was rationalized in terms of intramolecular electron transfer from Tyr to $\operatorname{Met}(\mathrm{S}: \mathrm{N})^{+}$radical cations (see Scheme 15) [109].
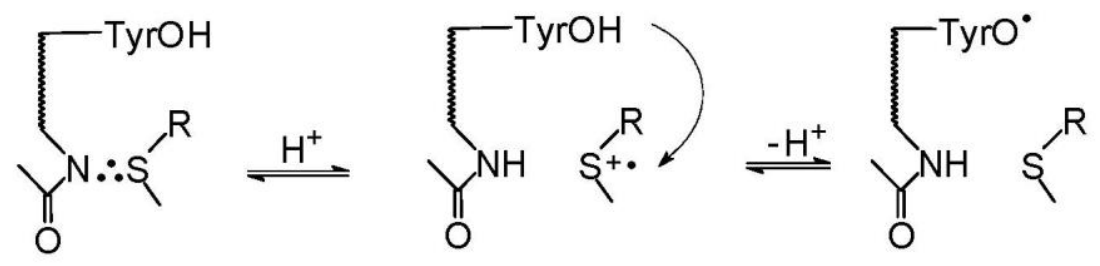

Scheme 15. electron transfer between $\operatorname{Met}(\mathrm{S} \cdot \mathrm{N})^{+}$and Tyr in $\mathrm{CaM}-\mathrm{Ca}_{4}$ (adapted from [109]).

\subsection{Photo-Induced Oxidation}

Despite the significant role of protein oxidation reactions in biology and medicine the sensitized photooxidation of Met within proteins was the subject of only a few papers. This may be due to complexity of the reactants, the diversity of possible target positions in the oxidation of proteins, and the experimental difficulties in analyzing the oxidation products. The mechanism of CB-sensitized photooxidation of plant cytokinin-specific binding proteins $(\mathrm{VrPhBP})$ was recently studied using nanosecond flash photolysis and various methods for analyzing the stable photoproducts (chemical analysis, silver-staining gel electrophoresis, chromatography, and mass spectrometry including peptide mapping by proteolysis and coupling with chromatography) [110]. The results indicated oxidation of methionine and tyrosine residues within the protein.

Based on the crystallographic structure of the $\mathrm{VrPhBP}$ protein and taking into account knowledge from similar studies for model amino acids and peptides, methionine (Met ${ }^{141}$ ) and tyrosine $\left(\mathrm{Tyr}^{142}\right)$ residues were suggested as being the most prone to oxidation. It was shown that the $C B$ triplets were mainly quenched by methionine and partially by tyrosine 
residues via the electron transfer mechanism leading to the formation of sulfur-centered monomeric radical cations $>\mathrm{S}^{\cdot+}$ (stabilized by $\left(\mathrm{S} \cdot{ }^{\circ} \mathrm{N}\right)^{+}$formation), tyrosyl radicals TyrO and ketyl radicals $\mathrm{CBH}$. As was already shown for the model peptide (Met-enkephalin) [61], the intramolecular electron transfer from the Tyr residue to the oxidized sufur atom of the Met residue can take place leading to regeneration of the Met residue and formation of additional TyrO radicals. The presence of the transient species observed in the timeresolved experiments were additionally confirmed by the detection of such stable products as methionine sulfoxide, the Met-CBH adduct (radical coupling products $(\alpha \mathrm{S}-\mathrm{CBH})$ and dityrosine cross links (see Scheme 16). The results from the study of sensitized photooxidation of model compounds including methionine derivatives and peptides were very helpful to understand the mechanism of sensitized photoxidation of proteins containing methionine residues.

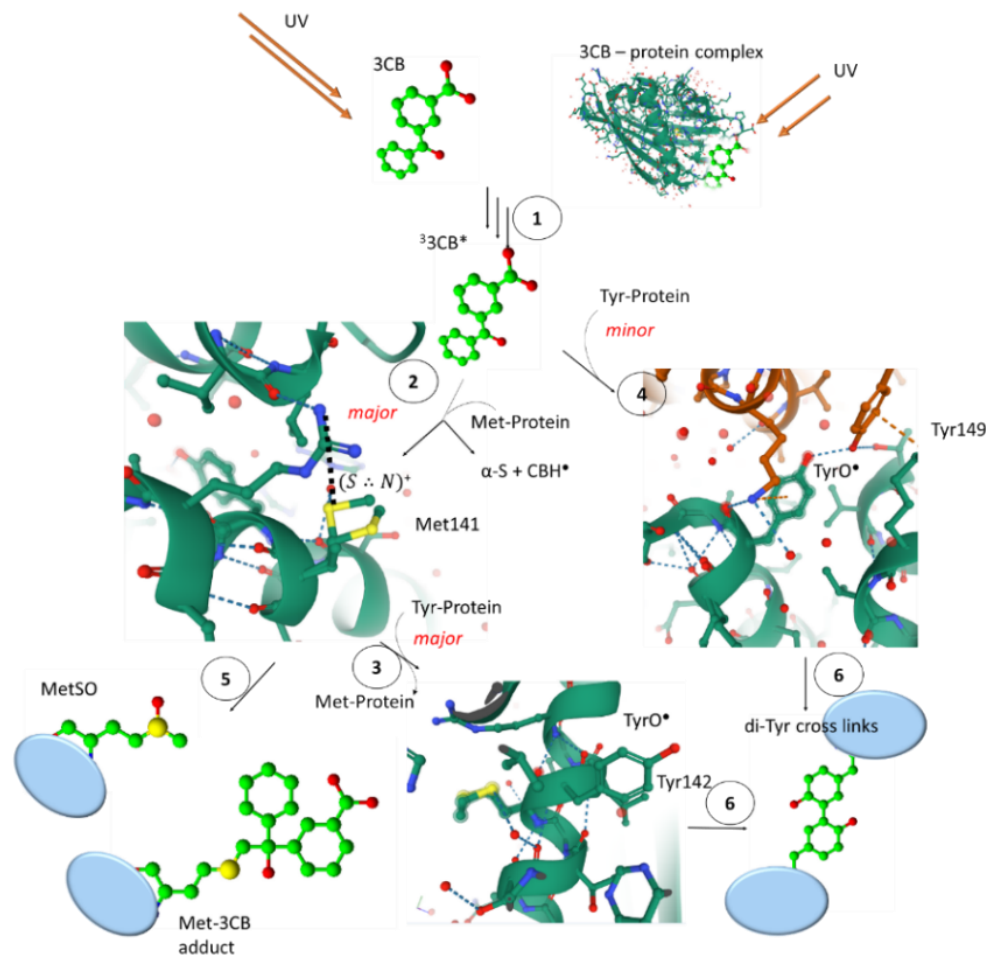

Scheme 16. Graphical scheme reaction of the mechanism of $\mathrm{VrPhBp}$ protein oxidation sensitized by CB in aqueous solutions methionine in Gly-Met-Gly tripeptide (adapted from [110]).

\section{Conclusions}

A wealth of knowledge has been accumulated over the years concerning the mechanistic understanding of one-electron oxidation of methionine in various structural environments using two-complementary radiation and photochemical time-resolved techniques such as pulse radiolysis and laser flash photolysis coupled with UV-vis spectrophotometry, conductometry, ESR spectroscopy and CIDNP. Creation of a variety of very reactive transients such as ${ }^{\bullet} \mathrm{OH}$-adducts to methionine (MetS: $\mathrm{OH}$ ), monomeric sulfur radical cations $\left(\mathrm{MetS}^{\bullet+}\right)$, intramolecularly $(\mathrm{S}: \mathrm{N})$-bonded radicals $(\mathrm{Met}(\mathrm{S} \cdot \mathrm{N})$ ) or radical cations $\left(\operatorname{Met}(\mathrm{S}: \mathrm{N})^{+}\right), \alpha$-alkylthio)alkyl radicals $(\alpha \mathrm{S} 1, \alpha \mathrm{S} 2), \alpha$-aminoalkyl radicals $(\alpha \mathrm{N})$ intermolecularly S: .S-bonded dimeric radical cations ((MetS: SMet) $\left.)^{+}\right)$, intramolecularly S. .S-bonded radical cations $\left(\operatorname{Met}(\mathrm{S}: \mathrm{S})^{+}\right)$, and intramolecularly $\mathrm{S}: \mathrm{O}$-bonded radical cations $\left(\mathrm{Met}(\mathrm{S} \cdot: \mathrm{O})^{+}\right)$, which are precursors for the subsequent final products responsible for protein damage, requires a knowledge of their spectral parameters as well as the mechanisms of their formation and decay along with appropriate kinetic parameters. Neighboring group participation seems to be an essential parameter which controls one-electron oxidation of methionine by various one-electron oxidants in various structural and $\mathrm{pH}$ environments. Provided 
that photo- and radiation-induced reaction pathways lead to the formation of a common intermediate, namely the monomeric sulfur-centered radical cation $\left(\mathrm{Met} \mathrm{S}^{\bullet+}\right.$ ), its secondary reactions in peptides and proteins will be the same. This review was also aimed at demonstrating the complementarity of photo- and radiation-chemical studies using the example of methionine oxidation processes.

Future studies on photo- and radiation-induced oxidation of Met containing compounds aimed at analysis of stable products formed during the steady state photo- and $\gamma$-irradiations (similar to those reported in the references $[20,22,59,76]$ are expected to help in understanding the overall mechanism of oxidation from short-lived intermediates to the final products.

Author Contributions: Conceptualization, B.M. and K.B.; writing-original draft preparation, B.M. and K.B.; writing-review and editing B.M. and K.B. All authors have read and agreed to the published version of the manuscript.

Funding: This research was funded by the Polish National Science Centre (NCN) under grant no. UMO 2017/27/B/ST4/00375 (B.M.) and by statutory funds of the Institute of Nuclear Chemistry and Technology (INCT) (K.B.)

Institutional Review Board Statement: Not applicable.

Informed Consent Statement: Not applicable.

Data Availability Statement: Not applicable.

Acknowledgments: We acknowledge the co-authors of our papers cited in the references for the fruitful exchange of ideas and collaborations. We are very grateful to Gordon L. Hug from the Notre Dame Radiation Laboratory (USA) for his insightful comments and helpful suggestions. Thanks are also due to Konrad Skotnicki (K.B.) and Jarogniew Bartoszewicz (B.M.) for their invaluable help in editing schemes presented in the manuscript.

Conflicts of Interest: The authors declare no conflict of interest. The funders had no role in the design of the study; in the collection, analyses, or interpretation of data; in the writing of the manuscript, or in the decision to publish the results.

\section{References}

1. Levine, R.L.; Mosoni, L.; Berlett, B.S.; Stadtman, E.R. Methionine residues as endogenous antioxidants in proteins. Proc. Natl. Acad. Sci. USA 1996, 93, 15036-15040. [CrossRef] [PubMed]

2. Vogt, W. Oxidation of Methionyl Residues in Proteins: Tools, Targets, and Reversal. Free Radic. Biol. Med. 1995, 18, 93-105. [CrossRef]

3. Davies, M. The oxidative environment and protein damage. Biochim. Biophys. Acta 2005, 1703, 93-109. [CrossRef] [PubMed]

4. Stadtman, E.R.; Van Remmen, H.; Richardson, A.; Wehr, N.B.; Levine, R.L. Methionine oxidation and aging. Biochim. Biophys. Acta 2005, 1703, 135-140. [CrossRef] [PubMed]

5. Houée-Levin, C.; Bobrowski, K. The use of methods of radiolysis to explore the mechanisms of free radical modifications in proteins. J. Proteom. 2013, 92, 51-62. [CrossRef] [PubMed]

6. Ignasiak, M.T.; Marciniak, B.; Houée-Levin, C. A Long Story of Sensitized One-Electron Photo-oxidation of Methionine. Isr. J. Chem. 2014, 54, 248-253. [CrossRef]

7. Hiller, K.-O.; Masloch, B.; Göbl, M.; Asmus, K.-D. Mechanism of the OH' radical induced oxidation of methionine in aqueous solution. J. Am. Chem. Soc. 1981, 103, 2734-2743. [CrossRef]

8. Bobrowski, K.; Holcman, J. Formation of three-electron bonds in one-electron oxidized methionine dipeptides: A pulse radiolytic study. Int. J. Radiat. Biol. Relat. Stud. Phys. Chem. Med. 1987, 52, 139-144. [CrossRef]

9. Bobrowski, K.; Holcman, J. Formation and stability of intramolecular three-electron S. N, S. S, and S. .O bonds in one-electronoxidized simple methionine peptides. Pulse radiolysis study. J. Phys. Chem. 1989, 93, 6381-6387. [CrossRef]

10. Schöneich, C.; Pogocki, D.; Wisniowski, P.; Hug, G.L.; Bobrowski, K. Intramolecular Sulfur-Oxygen Bond Formation in Radical Cations of N-Acetylmethionine Amide. J. Am. Chem. Soc. 2000, 122, 10224-10225. [CrossRef]

11. Schöneich, C.; Pogocki, D.; Hug, G.L.; Bobrowski, K. Free radical reactions of methionine in peptides: Mechanisms relevant to $\beta$-amyloid oxidation and Alzheimer's disease. J. Am. Chem. Soc. 2003, 125, 13700-13713. [CrossRef]

12. Bobrowski, K.; Hug, G.L.; Pogocki, D.; Marciniak, B.; Schöneich, C. Stabilization of sulfide radical cations through complexation with the peptide bond: Mechanisms relevant to oxidation of proteins containing multiple methionine residues. J. Phys. Chem. $B$ 2007, 111, 9608-9620. [CrossRef] 
13. Hug, G.L.; Bobrowski, K.; Pogocki, D.; Hörner, G.; Marciniak, B. Conformational influence on the type of stabilization of sulfur radical cations in cyclic peptides. ChemPhysChem 2007, 8, 2202-2210. [CrossRef]

14. Schöneich, C.; Zhao, F.; Madden, K.P.; Bobrowski, K. Side chain fragmentation of N-terminal threonine or serine residue induced through intramolecular proton transfer to hydroxy sulfuranyl radical formed at neighboring methionine in dipeptides. J. Am. Chem. Soc. 1994, 116, 4641-4652. [CrossRef]

15. Bobrowski, K.; Marciniak, B.; Hug, G.L. 4-Carboxybenzophenone-sensitized photooxidation of sulfur-containing amino acids. Nanosecond laser flash photolysis and pulse radiolysis studies. J. Am. Chem. Soc. 1992, 114, 10279-10288. [CrossRef]

16. Marciniak, B.; Hug, G.L.; Bobrowski, K.; Kozubek, H. Mechanism of 4-carboxybenzophenone-sensitized photooxidation of methionine-containing dipeptides and tripeptides in aqueous solution. J. Phys. Chem. 1995, 99, 13560-13568. [CrossRef]

17. Hug, G.L.; Marciniak, B.; Bobrowski, K. Acid-base equilibria involved in secondary reactions following the 4-carboxybenzophenone sensitized photooxidation of methionyl-glycine in aqueous solution. Spectral and time resolution of the decaying $\left(\mathrm{S} \cdot{ }^{\cdot} \mathrm{N}\right)^{+}$radical cation. J. Phys. Chem. 1996, 100, 14914-14921. [CrossRef]

18. Hug, G.L.; Marciniak, B.; Bobrowski, K. Sensitized photo-oxidation of sulfur-containing amino acids and peptides in aqueous solution. J. Photochem. Photobiol. A 1996, 95, 81-88. [CrossRef]

19. Hug, G.L.; Bobrowski, K.; Kozubek, H.; Marciniak, B. Photooxidation of Methionine Derivatives by the 4-Carboxybenzophenone Triplet State in Aqueous Solution. Intramolecular Proton Transfer involving the Amino Group. Photochem. Photobiol. 1998, 68, 785-796. [CrossRef]

20. Ignasiak, M.T.; Pedzinski, T.; Rusconi, F.; Filipiak, P.; Bobrowski, K.; Houée-Levin, C.; Marciniak, B. Photosensitized Oxidation of Methionine-Containing Dipeptides. From the Transients to the Final Products. J. Phys. Chem. B 2014, 118, 8549-8558. [CrossRef]

21. Pedzinski, T.; Markiewicz, A.; Marciniak, B. Photosensitized oxidation of methionine derivatives. Laser flash photolysis studies. Res. Chem. Intermed. 2009, 35, 497-506. [CrossRef]

22. Pedzinski, T.; Grzyb, K.; Kaźmierczak, F.; Frański, R.; Filipiak, P.; Marciniak, B. Early Events of Photosensitized Oxidation of Sulfur-Containing Amino Acids Studied by Laser Flash Photolysis and Mass Spectrometry. J. Phys. Chem. B 2020, 124, 7564-7573. [CrossRef] [PubMed]

23. Goez, M.; Rozwadowski, J.; Marciniak, B. CIDNP spectroscopic observation by magnetic resonance of SN+ radical cations with two-center-three-electron-bond during the photooxidation of methionine. Angew. Chem. Int. Ed. 1998, 37, 785-796. [CrossRef]

24. Morozova, O.B.; Korchak, S.E.; Vieth, H.-M.; Yurkovskaya, A.V. Photo-CIDNP Study of Transient Radicals of Met-Gly and Gly-Met Peptides in Aqueous Solution at Variable pH. J. Phys. Chem. B 2009, 113, 7398-7406. [CrossRef]

25. Köchling, T.; Morozova, O.B.; Yurkovskaya, A.V.; Vieth, H.-M. Magnetic Resonance Characterization of One-Electron Oxidized Cyclic Dipeptides with Thioether Groups. J. Phys. Chem. B 2016, 120, 9277-9286. [CrossRef] [PubMed]

26. Yashiro, H.; White, R.C.; Yurkovskaya, A.V.; Forbes, M.D.E. Methionine Radical Cation: Structural Studies as a Function of pH Using X- and Q-Band Time-Resolved Electron Paramagnetic Resonance Spectroscopy. J. Phys. Chem. A 2005, 109, 5855-5864. [CrossRef] [PubMed]

27. Bobrowski, K.; Houée-Levin, C.; Marciniak, B. Stabilization and Reactions of Sulfur Radical Cations: Relevance to One-Electron Oxidation of Methionine in Peptides and Proteins. Chimia 2008, 62, 728-734. [CrossRef]

28. Schöneich, C. Redox processes of methionine relevant to $\beta$-amyloid oxidation and Alzheimer's disease. Arch. Biochem. Biophys. 2002, 397, 370-376. [CrossRef]

29. Schöneich, C. Methionine oxidation by reactive oxygen species: Reaction mechanisms and relevance to Alzheimer's disease. Biochim. Biophys. Acta 2005, 1703, 111-119. [CrossRef]

30. Glass, R.S. Sulfur Radicals and Their Application. Top. Curr. Chem. 2018, 376, 22. [CrossRef]

31. Schöneich, C.; Zhao, F.; Yang, J.; Miller, B. Mechanisms of Methionine Oxidation in Peptides. In Therapeutic Protein and Peptide Formulation and Delivery; Shahrokh, Z., Sluzky, V., Cleland, J.L., Shire, S.J., Randolph, T.W., Eds.; ACS Symposium Series; American Chemical Society: Washington, DC, USA, 1997; Volume 675, pp. 79-89.

32. Bobrowski, K. Chemistry of Sulfur-centered Radicals. In Recent Trends in Radiation Chemistry; Wishart, J.F., Rao, B.S.M., Eds.; World Scientific: Singapore, 2010.

33. Bobrowski, K. Radiation-induced radicals and radical ions in amino acids and peptides. In Selectivity, Control, and Fine Tuning in High Energy Chemistry; Staas, D.V., Feldman, V.I., Eds.; Research Signpost: Trivandrum, India, 2011.

34. Houée-Levin, C. One-electron redox processes in proteins. In Selectivity, Control, and Fine Tuning in High-Energy Chemistry; Stass, D.V., Feldman, V.I., Eds.; Research Signpost: Trivandrum, India, 2011; p. 59.

35. Schöneich, C. Radical-Based Damage of Sulfur-Containing Amino Acid Residues. In Encyclopedia of Radical in Chemistry, Biology and Materials; Chatgilialoglu, C., Studer, A., Eds.; Chemical Biology; John Wiley \& Sons, Ltd.: Chichester, UK, 2012; Volume 3, pp. 1459-1474.

36. Capon, B.; Mc Manus, S.P. Neighboring Group Participation; Plenum Press: New York, NY, USA, 1976 ; Volume 1.

37. Glass, R.S.; Hug, G.L.; Schöneich, C.; Wilson, G.S.; Kuznetsova, L.; Lee, T.; Ammam, M.; Lorance, E.; Nauser, T.; Nichol, G.S.; et al. Neighboring Amide Participation in Thioether Oxidation: Relevance to Biological Oxidation. J. Am. Chem. Soc. 2009, 131, 13791-13805. [CrossRef]

38. Fourre, I.; Silvi, B. What Can We Learn from Two-Center Three-Electron Bonding with the Topological Analysis of ELF? Heteroat. Chem. 2007, 18, 135-160. [CrossRef] 
39. Fourre, I.; Bergès, J.; Houée-Levin, C. Structural and Topological Studies of Methionine Radical Cations in Dipeptides: Electron Sharing in Two-Center Three-Electron Bonds. J. Phys. Chem. A 2010, 114, 7359-7368. [CrossRef]

40. Brunelle, P.; Rauk, A. One-electron oxidation of methionine in peptide environments: The effect of three-electron bonding on the reduction potential of the radical cation. J. Phys. Chem. A 2004, 108, 11032-11041. [CrossRef]

41. Asmus, K.-D. Sulfur-centered three-electron bonded radical species. In Sulfur-Centered Reactive Intermediates in Chemistry and Biology; Chatgilialoglu, C., Asmus, K.-D., Eds.; NATO ASI Series, Series A: Life Sciences; Plenum Press: New York, NY, USA, 1990; Volume 197, pp. 155-172.

42. Asmus, K.-D. Sulfur-centered Free Radicals. In Methods in Enzymology; Packer, L., Ed.; Academic Press: Orlando, FL, USA, 1990; Volume 186, pp. 168-180.

43. Hiller, K.-O.; Asmus, K.-D. $\mathrm{Tl}^{2+}$ and $\mathrm{Ag}^{2+}$ metal-ion-induced oxidation of methionine in aqueous solution. A pulse radiolysis study. Int. J. Radiat. Biol. Relat. Stud. Phys. Chem. Med. 1981, 40, 597-604. [CrossRef]

44. Hiller, K.-O.; Asmus, K.-D. Formation and reduction reactions of $\alpha$-amino radicals derived from methionine and its derivatives in aqueous solutions. J. Phys. Chem. 1983, 87, 3682-3688. [CrossRef]

45. Mönig, J.; Göbl, M.; Asmus, K.-D. Free Radical One-electron versus Hydrogen Radical-induced Oxidation. Reaction of Trichloromethyl Peroxyl Radicals with Simple and Substituted Aliphatic Sulphides in Aqueous Solution. J. Chem. Soc. Perkin Trans. 1985, 647. [CrossRef]

46. Asmus, K.-D.; Göbl, M.; Hiller, K.-O.; Mahling, S.; Mönig, J. S. :N and S. :O three-electron-bonded radicals and radical cations in aqueous solutions. J. Chem. Soc. Perkin Trans. 2 1985, 641-646. [CrossRef]

47. Armstrong, D.A.; Huie, R.E.; Koppenol, W.H.; Lymar, S.V.; Merenyi, G.; Neta, P.; Ruscic, B.; Stanbury, D.M.; Steenken, S.; Wardman, P. Standard electrode potentials involving radicals in aqueois solutions: Inorganic radicals (IUPAC Technical Report). Pure Appl. Chem. 2015, 87, 1139-1150. [CrossRef]

48. Rauk, A.; Armstrong, D.A.; Fairlie, D.P. Is oxidative damage by $\beta$-amyloid and prion peptides mediated by hydrogen atom transfer from glycyne $\alpha$-carbon to methionine sulfur within $\beta$-sheets? J. Am. Chem. Soc. 2000, 122, 9761-9767. [CrossRef]

49. Merényi, G.; Lind, J.; Engman, L. One- and Two-electron reduction Potentials of Peroxyl Radicals and Related Species. J. Chem. Soc. Perkin Trans. 2 1994, 2551-2553. [CrossRef]

50. Chen, S.N.; Hoffman, M.Z. Rate constants for the reaction of the carbonate radical with compounds of biochemical interest in neutral aqueous solution. Radiat. Res. 1973, 56, 40-47. [CrossRef]

51. Wojnárovits, L.; Takács, E. Rate constants of dichloride radical anion reactions with molecules of environmental interest in aqueous solution: A review. Environ. Sci. Pollut. Res. 2021, 28, 41552-41575. [CrossRef]

52. Hiller, K.-O.; Asmus, K.-D. Oxidation of methionine by $\mathrm{X}_{2}{ }^{-}$in aqueous solution and characterization of some $>S X$ three-electron bonded intermediates. A pulse radiolysis study. Int. J. Radiat. Biol. 1981, 40, 583-595.

53. Bonifačić, M.; Asmus, K.-D. Stabilization of oxidized sulfur centres by halide ions. Formation and properties of $\mathrm{R}_{2} \mathrm{SX}$ radicals in aqueous solutions. J. Chem. Soc. Perkin Trans. 2 1980, 758-762. [CrossRef]

54. Pogocki, D.M. Investigation of Radical Processes Induced by Hydroxyl Radical in Amino Acids and Peptides Containing Thioether Group. Ph.D. Thesis, Institute of Nuclear Chemistry and Technology, Warsaw, Poland, 1996.

55. Mishra, B.; Priyadarsini, K.I.; Mohan, H. Pulse radiolysis studies on reaction of OH radical with N-acetyl methionine in aqueous solutions. Res. Chem. Interm. 2005, 31, 625-632. [CrossRef]

56. Shirdhonkar, M.; Maity, D.K.; Mohan, H.; Rao, B.S.M. Oxidation of methionine methyl ester in aqueous solution: A combined pulse radiolysis and quantum chemical study. Chem. Phys. Lett. 2006, 417, 116-123. [CrossRef]

57. Bobrowski, K.; Schöneich, C.; Holcman, J.; Asmus, K.-D. ${ }^{\bullet} \mathrm{OH}$ radical induced decarboxylation of methionine-containing peptides. Influence of peptide sequence and net charge. J. Chem. Soc., Perkin Trans. 2 1991, 353-362. [CrossRef]

58. Steffen, L.K.; Glass, R.S.; Sabahi, M.; Wilson, G.S.; Schöneich, C.; Mahling, S.; Asmus, K.-D. 'OH radical induced decarboxylation of amino acids. Decarboxylation vs bond formation in radical intermediates. J. Am. Chem. Soc. 1991, 113, 2141-2145. [CrossRef]

59. Pedzinski, T.; Grzyb, K.; Skotnicki, K.; Filipiak, P.; Bobrowski, K.; Chatgilialoglu, C.; Marciniak, B. Radiation- and Photo-Induced Oxidation Pathways of Methionine in Model Peptide Backbone under Anoxic Conditions. Int. J. Mol. Sci. 2021, $22,4773$. [CrossRef]

60. Guttenplan, J.B.; Cohen, S.G. Quenching and reduction of photoexcited benzophenone by thioethers and mercaptans. J. Org. Chem. 1973, 38, 2001-2007. [CrossRef]

61. Wojcik, A.; Lukaszewicz, A.; Brede, O.; Marciniak, B. Competitive photosensitized oxidation of tyrosine and methionine residues in enkephalins and their model peptides. J. Photochem. Photobiol. A Chem. 2008, 198, 111-118. [CrossRef]

62. Marciniak, B.; Bobrowski, K.; Hug, G.L. Quenching of triplet states of aromatic ketones by sulfur-containing amino acids in solution. Evidence for electron transfer. J. Phys. Chem. 1993, 97, 11937-11943. [CrossRef]

63. Hug, G.L.; Bobrowski, K.; Kozubek, H.; Marciniak, B. Photo-oxidation of Methionine-containing Peptides by the 4-Carboxybenzophenone Triplet State in Aqueous Solution. Competition between Intramolecular Two-centered Three-electron Bonded $(\mathrm{S} \cdot \mathrm{S})^{+}$and $(\mathrm{S} \cdot \mathrm{N})^{+}$Formation. Photochem. Photobiol. 2000, 72, 1-9. [CrossRef]

64. Cohen, S.G.; Ojanpera, S. Photooxidation of methionine and related compounds. J. Am. Chem. Soc. 1975, 97, 5633-5634. [CrossRef]

65. Encinas, M.V.; Lissi, E.A.; Olea, A.F. Quenching of triplet benzophenone by vitamins $\mathrm{E}$ and $\mathrm{C}$ and by sulfur containing aminoacids and peptides. Photochem. Photobiol. 1985, 42, 347-352. [CrossRef] 
66. Encinas, M.V.; Lissi, E.A.; Vasquez, M.; Olea, A.F.; Silva, E. Photointeraction of benzophenone triplet with lysozyme. Photochem. Photobiol. 1989, 49, 557-563. [CrossRef] [PubMed]

67. Bobrowski, K.; Hug, G.L.; Marciniak, B.; Kozubek, H. 4-Carboxybenzophenone-sensitized photooxidation of sulfur-containing amino acids in alkaline aqueous solutions. Secondary photoreactions kinetics. J. Phys. Chem. 1994, 98, 537-544. [CrossRef]

68. Filipiak, P.; Bobrowski, K.; Hug, G.L.; Pogocki, D.; Schöneich, C.; Marciniak, B. New Insights into the Reaction Paths of 4Carboxybenzophenone Triplet with Oligopeptides Containing N- and C-Terminal Methionine Residues. J. Phys. Chem. B 2017, 121, 5247-5258. [CrossRef]

69. Goez, M.; Rozwadowski, J. Reversible Pair Substitution in CIDNP: The Radical Cation of Methionine. J. Phys. Chem. A 1998, 102, 7945-7953. [CrossRef]

70. Bonifačić, M.; Stefanic, I.; Hug, G.L.; Armstrong, D.A.; Asmus, K.-D. Glycine decarboxylation: The free radical mechanism. J. Am. Chem. Soc. 1998, 120, 9930-9940. [CrossRef]

71. Marciniak, B.; Hug, G.L.; Rozwadowski, J.; Bobrowski, K. Excited Triplet State of N-(9-methylpurin-6-yl)pyridinium Cation as as Efficient Photosensitizer in the Oxidation of Sulfur-containing Amino Acids. Laser Flash and Steady-state Photolysis Studies. J. Am. Chem. Soc. 1995, 117, 127-134. [CrossRef]

72. Bobrowski, K.; Hug, G.L.; Pogocki, D.; Marciniak, B.; Schöneich, C. Sulfur radical cation peptide bond complex in the one-electron oxidation of S-methylglutathione. J. Am. Chem. Soc. 2007, 129, 9236-9245. [CrossRef] [PubMed]

73. Filipiak, P.; Hug, G.L.; Bobrowski, K.; Pedzinski, T.; Kozubek, H.; Marciniak, B. Sensitized Photooxidation of S-Methylglutathione in Aqueous Solution: Intramolecular (S. :O) and (S. :N) Bonded Species. J. Phys. Chem. B 2013, 117, 2359-2368. [CrossRef]

74. Barata-Vallejo, S.; Ferreri, C.; Zhang, T.; Permentier, H.; Bischoff, R.; Bobrowski, K.; Chatgilialoglu, C. Radiation chemical studies of Gly-Met-Gly in aqueous solution. Free Rad. Res. 2016, 50, S24-S39. [CrossRef]

75. Hug, G.L.; Bobrowski, K.; Kozubek, H.; Marciniak, B. pH effects on the photooxidation of methionine derivatives by the 4-carboxybenzophenone triplet state. Nukleonika 2000, 45, 63-71.

76. Lewandowska-Andralojć, A.; Kazmierczak, F.; Hug, G.L.; Hörner, G.; Marciniak, B. Photoinduced CC-coupling Reactions of Rigid Diastereomeric Benzophenone-Methionine Dyads. Photochem. Photobiol. 2013, 89, 14-23. [CrossRef]

77. Ignasiak, M.T. Study of the Mechanism of Radiation- and Photo-Induced Oxidation of Methionine Containing Peptides. Ph.D. Thesis, Adam Mickiewicz University, Poznań, Poland, 2014.

78. Bonifačić, M.; Hug, G.L.; Schöneich, C. Kinetics of the reactions between sulfide radical cation complexes, [S. :S $]^{+}$and [S. :N] ${ }^{+}$, and superoxide or carbon dioxide radical anions. J. Phys. Chem. A 2000, 104, 1240-1245. [CrossRef]

79. Klug, D.; Rabani, J.; Fridovich, I. A direct demonstration of the catalytic action of superoxide dismutase through the use of pulse radiolysis. J. Biol. Chem. 1972, 247, 4839-4842. [CrossRef]

80. Bobrowski, K.; Schöneich, C.; Holcman, J.; Asmus, K.-D. ${ }^{\bullet} \mathrm{OH}$ radical induced decarboxylation of $\gamma$-glutamylmethionine and S-alkylglutathione derivatives: Evidence for two different pathways involving C-and N-terminal decarboxylation. J. Chem. Soc. Perkin Trans. 2 1991, 975-980. [CrossRef]

81. Bobrowski, K.; Schöneich, C. Decarboxylation mechanism of the N-terminal glutamyl moiety in $\gamma$-glutamic acid and methionine containing peptides. Radiat. Phys. Chem. 1996, 47, 507-510. [CrossRef]

82. Filipiak, P.; Bobrowski, K.; Hug, G.L.; Schöneich, C.; Marciniak, B. N-Terminal Decarboxylation as a Probe for Intramolecular Contact Formation in $\gamma$-Glu-(Pro)n-Met Peptides. J. Phys. Chem. B 2020, 124, 8082-8098. [CrossRef]

83. Harriman, A. Further comment on the redox potentials of tryptophan and tyrosine. J. Phys. Chem. 1987, 91, 6102-6104. [CrossRef]

84. Folkes, L.K.; Trujillo, M.; Bartesaghi, S.; Radi, R.; Wardman, P. Kinetics of reduction of tyrosine phenoxyl radicals by glutathione. Arch. Biochem. Biophys. 2011, 506, 242-249. [CrossRef]

85. Merenyi, G.; Lind, J.; Engman, L. The Dimethylhydroxysulfuranyl Radical. J. Phys. Chem. 1996, 100, 8875-8881. [CrossRef]

86. Stryer, L. Biochemistry; W. H. Freeman and Company: New York, NY, USA, 1988.

87. Mozziconacci, O.; Mirkowski, J.; Rusconi, F.; Kciuk, G.; Wisniowski, P.; Bobrowski, K.; Houée-Levin, C. Methionine residue acts as a prooxidant in the $\mathrm{OH}$-induced oxidation of enkephalins. J. Phys. Chem B 2012, 116, 9352-9362. [CrossRef]

88. Buxton, G.V.; Greenstock, C.L.; Helman, W.P.; Ross, A.B. Critical review of rate constants for reactions of hydrated electrons, hydrogen atoms and hydroxyl radicals $\left(\cdot \mathrm{OH} / \mathrm{O}^{-}\right)$in aqueous solution. J. Phys. Chem. Ref. Data 1988, 17, 513-886. [CrossRef]

89. Bobrowski, K.; Wierzchowski, K.L.; Holcman, J.; Ciurak, M. Intramolecular electron transfer in peptides containing methionine, tryptophan, and tyrosine: A pulse radiolysis study. Int. J. Radiat. Biol. 1990, 57, 919-932. [CrossRef]

90. Bobrowski, K.; Wierzchowski, K.L.; Holcman, J.; Ciurak, M. Pulse radiolysis, of intramolecular electron transfer in model peptides. IV. Met/S. : Br -> Tyr/O radical transformation in aqueous solution of H-Tyr-(Pro) $)_{n}$-Met-OH peptides. Int. J. Radiat. Biol. 1992, 62, 507-516. [CrossRef]

91. Bergès, J.; Trouillas, P.; Houée-Levin, C. Oxidation of protein tyrosine, or methionine residues: From the amino acid to the peptide. J. Phys. Conf. Ser. 2011, 261, 012003. [CrossRef]

92. Kadlčik, V.; Sicard-Roselli, C.; Mattioli, T.A.; Kodiček, M.; Houée-Levin, C. One-electron oxidation of $\beta$-amyloid peptide: Sequence modulation of reactivity. Free Radic. Biol. Med. 2004, 37, 881-891. [CrossRef] [PubMed]

93. Pogocki, D.; Schöneich, C. Redox properties of $\mathrm{Met}^{35}$ in neurotoxic $\beta$-amyloid peptide. A molecular modeling study. Chem. Res. Toxicol. 2002, 15, 408-418. [CrossRef] [PubMed]

94. Butterfield, D.A.; Bush, A.I. Alzheimer's amyloid $\beta$-peptide (1-42): Involvement of methionine residue 35 in the oxidative stress and neurotoxicity properties of this peptide. Neurobiol. Aging 2004, 25, 563-568. [CrossRef] [PubMed] 
95. Kanski, J.; Varadarajan, S.; Aksenova, M.; Butterfield, D.A. Role of glycine-33 and methionine-35 in Alzheimer's amyloid beta peptide 1-42-associated oxidative stress and neurotoxicity. Biochim. Biophys. Acta 2001, 1586, 190-198. [CrossRef]

96. Varadarajan, S.; Yatin, S.; Kanski, J.; Jahanshahi, F.; Butterfield, D.A. Methionine residue 35 is important in amyloid beta peptide-associated free radical oxidative stress. Brain Res. Bull. 1999, 50, 133-141. [CrossRef]

97. Butterfield, D.A.; Kimball-Boyd, D. The critical role of methionine 35 in Alzheimer's amyloid $\beta$-peptide (1-42)-induced oxidative stress and neurotoxicity. Biochim. Biophys. Acta 2005, 1703, 149-156. [CrossRef] [PubMed]

98. Asmus, K.-D. Stabilization of oxidized sulfur centers in organic sulfides. Radical cations and odd-electron sulfur-sulfur bonds. Acc. Chem. Res. 1979, 12, 436-442. [CrossRef]

99. Asmus, K.-D.; Bahnemann, D.; Fischer, C.-H.; Veltwisch, D. Structure and stability of radical cations from cyclic and open-chain dithia compounds in aqueous solutions. J. Am. Chem. Soc. 1979, 101, 5322-5329. [CrossRef]

100. Filipiak, P.; Bobrowski, K.; Hug, G.L.; Pogocki, D.; Schöneich, C.; Marciniak, B. Formation of a Three-Electron Sulfur-Sulfur Bond as a Probe for Interaction between Side Chains of Methionine Residues. J. Phys. Chem. B 2016, 120, 9732-9744. [CrossRef]

101. Zahn, R.; Liu, A.; Luhrs, T.; Riek, R.; Von Schroetter, C.; Lopez Garcia, F.; Billeter, M.; Calzolai, L.; Wider, G.; Wüthrich, K. NMR solution structure of the human prion protein. Proc. Nat. Acad. Sci. USA 2000, 97, 145-150. [CrossRef]

102. Glasser, C.B.; Yamin, G.; Uversky, V.N.; Fink, A.L. Methionine oxidation, $\alpha$-synuclein and Parkinson's disease. Biochim. Biophys. Acta 2005, 1703, 157-169. [CrossRef]

103. Kobayashi, K. Pulse Radiolysis Studies for Mechanism in Biochemical Redox Reactions. Chem. Rev. 2019, 119, 4413-4462. [CrossRef]

104. Bobrowski, K.; Holcman, J.; Poznanski, J.; Wierzchowski, K.L. Pulse radiolysis of intramolecular electron transfer in model peptides and proteins. 7. Trp $\rightarrow$ TyrO radical transformation in hen-egg white lysozyme. Effects of $\mathrm{pH}$, temperature, Trp62 oxidation and inhibitor binding. Biophys. Chem. 1997, 63, 153-166. [CrossRef]

105. Houée-Levin, C.; Bobrowski, K. Pulse radiolysis studies of free radical processes in peptides and proteins. In Radiation Chemistry: From Basics to Applications in Material and Life Sciences; Spotheim-Maurizot, M., Mostafavi, M., Douki, T., Belloni, J., Eds.; EDP Sciences: Bonchamp-Les Laval, France, 2008; pp. 233-247.

106. Butler, J.; Land, E.J.; Prütz, W.A.; Swallow, A.J. Charge transfer between tryptophan and tyrosine in proteins. Biochim. Biophys. Acta 1982, 705, 150-162. [CrossRef]

107. Audette-Stuart, M.; Blouquit, Y.; Faraggi, M.; Sicard-Roselli, C.; Houee-Levin, C.; Jolles, P. Re-evaluation of intramolecular long-range electron transfer between tyrosine and tryptophan in lysozymes. Eur. J. Biochem. 2003, 270, 3565-3571. [CrossRef]

108. Sicard-Roselli, C.; Lemaire, S.; Jacquot, J.-P.; Favaudon, V.; Marchand, C.; Houee-Levin, C. Thioredoxin Ch1 of Chlamydomonas reinhardtii displays an unusual resistance toward one-electron oxidation. Eur. J. Biochem. 2004, 271, 3481-3487. [CrossRef]

109. Nauser, T.; Jacoby, M.; Koppenol, W.H.; Squier, T.C.; Schöneich, C. Calmodulin methionine residues are targets for one-electron oxidation by hydroxyl radicals: Formation of S. N three-electron bonded radical complexes. Chem. Commun. 2005, 587-589. [CrossRef]

110. Ignasiak, M.; Nowicka-Bauer, K.; Grzechowiak, M.; Sikorski, M.; Shashikadze, B.; Jaskolski, M.; Marciniak, B. Sensitized photooxidation of plant cytokinin-specific binding protein-Does the environment of the thioether group influence the oxidation reaction? From primary intermediates to stable products. Free Radic. Biol. Med. 2021, 165, 411-420. [CrossRef] 